\title{
Review
}

\section{Slow Excitotoxicity in Alzheimer's Disease}

\author{
Wei-Yi Ong ${ }^{\mathrm{a}, \mathrm{b}, *}$, Kazuhiro Tanaka ${ }^{\mathrm{b}, \mathrm{c}}$, Gavin S. Dawe $\mathrm{e}^{\mathrm{b}, \mathrm{c}, \mathrm{d}}$, Lars M. Ittner ${ }^{\mathrm{e}}$ and Akhlaq A. Farooqui ${ }^{\mathrm{f}}$ \\ ${ }^{a}$ Department of Anatomy, Yong Loo Lin School of Medicine, National University Health System, National University \\ of Singapore, Singapore \\ ${ }^{\mathrm{b}}$ Neurobiology and Ageing Research Program, Life Sciences Institute, National University of Singapore, Singapore \\ ${ }^{\mathrm{c}}$ Department of Pharmacology, Yong Loo Lin School of Medicine, National University Health System, National \\ University of Singapore, Singapore \\ ${ }^{\mathrm{d}}$ Singapore Institute for Neurotechnology (SINAPSE), Singapore \\ ${ }^{\mathrm{e}}$ Brain and Mind Research Institute, The University of Sydney, NSW, Australia \\ ${ }^{\mathrm{f}}$ Department of Molecular and Cellular Biochemistry, The Ohio State University, Columbus OH, USA
}

\begin{abstract}
Progress is being made in identifying possible pathogenic factors and novel genes in the development of Alzheimer's disease (AD). Many of these could contribute to 'slow excitotoxicity', defined as neuronal loss due to overexcitation as a consequence of decreased energy production due, for instance, to changes in insulin receptor signaling; or receptor abnormalities, such as tau-induced alterations in $N$-methyl-D-aspartate (NMDA) receptor phosphorylation. As a result, glutamate becomes neurotoxic at concentrations that normally show no toxicity. In AD, NMDA receptors are overexcited by glutamate in a tonic, rather than a phasic manner. Moreover, in prodromal AD subjects, functional MRI reveals an increase in neural network activities relative to baseline, rather than loss of activity. This may be an attempt to compensate for reduced number of neurons, or reflect ongoing slow excitotoxicity. This article reviews possible links between AD pathogenic factors such as A $\beta P P / A \beta$ and tau; novel risk genes including clusterin, phosphatidylinositol-binding clathrin assembly protein, complement receptor 1, bridging integrator 1, ATP-binding cassette transporter 7, membrane-spanning 4-domains subfamily A, CD2-associated protein, sialic acid-binding immunoglobulin-like lectin, and ephrin receptor A1; metabolic changes including insulin resistance and hypercholesterolemia; lipid changes including alterations in brain phospholipids, cholesterol and ceramides; glial changes affecting microglia and astrocytes; alterations in brain iron metallome and oxidative stress; and slow excitotoxicity. Better understanding of the possible molecular links between pathogenic factors and slow excitotoxicity could inform our understanding of the disease, and pave the way towards new therapeutic strategies for AD.
\end{abstract}

Keywords: Alzheimer's disease, amyloid- $\beta$ peptide, tau, excitotoxicity, insulin resistance, phospholipase $\mathrm{A}_{2}$, cholesterd oxidation products, iron, memantine

\section{INTRODUCTION}

Alzheimer's disease (AD) is a progressive neurodegenerative disorder associated with memory

\footnotetext{
*Correspondence to: Dr. Wei-Yi Ong, PhD, Department of Anatomy, National University of Singapore, Singapore 119260. Tel.: +65 65163662; Fax: +65 67787643; E-mail: wei_yi_ong@ nuhs.edu.sg.
}

impairment and severe dementia. Neuropathological $\mathrm{AD}$ is characterized by accumulation of amyloid- $\beta$ peptide $(A \beta)$ neuritic plaques, neurofibrillary tangles, inflammation, and loss of synapses [1,2]. Although the molecular mechanisms associated with pathogenesis of $\mathrm{AD}$ are not clearly understood, $\mathrm{A} \beta$-mediated oxidative stress, induction of neuroinflammation, and abnormal glutamate metabolism have been implicated 
in onset and progression of the disease [1-5]. AD is a multifactorial disease with contributing factors such as aging, positive family history, unhealthy lifestyle and exposure to environmental toxicity [1,2]. Although no single lifestyle factor has conclusively been shown to alter the risk of $\mathrm{AD}$, evidence suggests that many risk factors for heart disease could also increase the risk of developing AD. These include lack of exercise, smoking, hypertension, hypercholesterolemia, and diabetes [6]. Other than variations in genes encoding amyloid- $\beta$ protein precursor (A $\beta P P)$, presenilin-1 (PSEN-1), and -2 (PSEN-2) that cause early-onset familial AD, a huge effort has been put in identifying gene loci that are associated with increased risk for sporadic AD [7]. It is now well-established that the homozygote apolipoprotein E4 (ApoE4) haplotype is associated with a significantly increased risk for sporadic AD. Moreover, a recent large genome-wide association study in lateonset AD has identified nine novel loci, and the authors of this study estimate genetic components to account for $60-80 \%$ of the disease [8]. These include clusterin, phosphatidylinositol-binding clathrin assembly protein (PICALM), complement receptor 1 (CR1), bridging integrator 1 (BIN1), ATP-binding cassette transporter 7 (ABCA7), membrane-spanning 4-domains subfamily A (MS4A cluster), CD2-associated protein (CD2AP), sialic acid-binding immunoglobulin-like lectin (CD33), and ephrin receptor A1 (EPHA1) [8]. As will be discussed below, many of these risk factors could have effects on slow excitotoxicity.

Excitotoxicity is defined as a process by which high levels of glutamate overexcite neurons and brings about cell death $[9,10]$. Glutamate or its analogs exert their effect on neurons by interacting with excitatory amino acid receptors on the post-synaptic cell membrane, including N-methyl-D-aspartate (NMDA), $\alpha$-amino-3-hydroxy-5-methyl-4-isoxazole propionate (AMPA), and kainate (KA) receptors [11, 12]. Excess stimulation of these receptors is accompanied by massive calcium influx initiating a cascade of events involving free radical generation, mitochondrial dysfunction, intracellular signaling cascades, such as p38 MAPK, extracellular signal-regulated kinase (ERK), and c-Jun N-terminal kinase, and activation of many calcium-dependent enzymes, including those involved in the generation and metabolism of arachidonic acid. The enzymes include isoforms of phospholipase $\mathrm{A}_{2}\left(\mathrm{PLA}_{2}\right)$, cyclooxygenase-2 (COX2), lipoxygenases (LOX), and epoxygenases (EPOX) [12]. Accumulation of oxygenated arachidonic acid metabolites through an uncontrolled "arachidonic acid cascade", along with lack of energy generation and abnormal ion homeostasis results in neural cell death.

High levels of glutamate damage glial cells by mechanisms that do not involve glutamate receptor activation, but rather glutamate uptake $[14,15]$. The latter is essential for maintaining excitatory postsynaptic currents, and preventing excitotoxicity due to overstimulation of glutamate receptors [16]. Out of five glutamate transporters cloned from brain tissue, at least two transporters, namely excitatory amino acid transporter 1 (EAAT1) and excitatory amino acid transporter 2 (EAAT2), are expressed in astrocytes, oligodendrocytes, and microglial cells. Exposure of astrocyte, oligodendrocyte, and microglial cell cultures to glutamate produces glial cell death by a transporter-related mechanism involving inhibition of cystine uptake, which causes a decrease in the antioxidant glutathione, and makes glial cells vulnerable to free radical injury [17].

The purpose of this article is to review: i) Evidence for slow excitotoxicity in $\mathrm{AD}$, ii) $\mathrm{AD}$ pathogenic factors, iii) AD pathogenic factors and slow excitotoxicity, iv) Possible links between novel $\mathrm{AD}$ risk genes and slow excitotoxicity, v) Possible links between AD associated metabolic changes and slow excitotoxicity, vi) Possible links between AD associated lipid changes and slow excitotoxicity, vii) Possible links between AD associated glial changes and slow excitotoxicity, viii) Possible links between AD associated iron changes and slow excitotoxicity, and ix) Treatment strategies for AD targeting slow excitotoxicity.

\section{EVIDENCE FOR SLOW EXCITOTOXICITY IN AD}

Two types of excitotoxicity are distinguished, a classical or acute, and a slow form. In 'classical excitotoxicity', acute elevation of glutamate is the key event inducing neuronal damage in conditions such as stroke, status epilepticus and traumatic brain and spinal cord injury. The increase in glutamate is due to release from damaged neurons or failure of glutamate transporters, and results in overexcitation of neurons. In contrast, 'slow excitotoxicity' in chronic neurodegenerative conditions is a consequence of decreased energy production or receptor abnormality [18]. For example, alterations in insulin signaling or disturbance of mitochondrial function can cause an impaired energy state of neurons. This results in decreased intracellular ATP levels and allows glutamate to become neurotoxic at concentrations that normally show no toxicity [19]. 
ATP is needed for ion pumps to maintain physiological intracellular calcium levels. When the cell membrane is depolarized from its usual $-90 \mathrm{mV}$ to between -60 and $-30 \mathrm{mV}$, the voltage-dependent $\mathrm{Mg}^{2+}$ block of the NMDA receptor is relieved, leading to its persistent activation. Partial neuronal depolarization induced by inhibitors of either glycolysis (iodoacetate) or oxidative phosphorylation (cyanide) results in NMDA receptor activation, in the absence of any increase in extracellular glutamate concentrations [20]. In addition, aminooxyacetic acid or 1-methyl-4-phenylpyridinium (MPP), which produces impaired mitochondrial energy metabolism, results in excitotoxic striatal lesions that are blocked by either glutamatergic denervation or NMDA receptor antagonists [21, 22]. Besides energy deficits, changes in cellular membranes may underlie receptor abnormalities that lead to slow excitotoxicity. Many $\mathrm{Ca}^{2+}$-dependent enzymes are involved in neural membrane phospholipid, sphingolipid, and cholesterol metabolism and breakdown of neuronal cytoarchitecture. They contribute to elevated levels of phospholipid-, sphingolipid-, and cholesterolderived lipid mediators, some of which have effects on the nucleus [23, 24]. Moreover, changes in membrane lipids may affect the structural properties of cell membranes and function of NMDA receptors, with possible implications for neuronal excitation and excitotoxicity [25].

NMDA receptors interact with various lipids and post synaptic density proteins (PSDs), such as PSD-95, to regulate downstream signaling pathways that mediate synaptic plasticity $[26,27]$. Under physiological conditions, low levels of phospholipid-, sphingolipid-, and cholesterol-derived lipid mediators are involved in signal transduction, adhesion, sorting, and trafficking. Under pathological conditions such as AD however, elevation in levels of lipid mediators is closely associated with neuronal injury [28, 29]. Neurochemical changes include glutamate-mediated activation of cytosolic $\mathrm{PLA}_{2}\left(\mathrm{cPLA}_{2}\right)$ and plasmalogen-selective $\mathrm{PLA}_{2}$ (PlsEtn-PLA $\mathrm{A}_{2}$ ), decrease in phosphatidylcholine and loss of plasmalogens, and reduction in the presynaptic vesicle protein synaptophysin $[30,31]$. It has been proposed that increased cross-talk between excitotoxicity, oxidative stress and neuroinflammation, along with elevated levels of phospholipid-, sphingolipid-, and cholesterol-derived lipid mediators in cytoplasmic and nuclear compartments may result in loss of synapses in $\mathrm{AD}[1,2]$. Aging, the major risk factor for $\mathrm{AD}$, causes synaptic loss in the dentate region of the hippocampus, but in advanced $\mathrm{AD}$, there is a disproportionately high loss of synapses, which corre- lates with the degree of dementia $[32,33]$. In addition, soluble $A \beta$ oligomers, also referred to as amyloid- $\beta$ derived diffusible ligands (ADDLs) act as highly specific pathogenic ligands for binding sites at synapses and promote synaptic loss [34]. This binding not only stimulates PlsEtn-PLA 2 [35], but also induces oxidative stress, loss of synapses, and ectopic redistribution of receptors crucial for plasticity and memory [34].

In $\mathrm{AD}$, NMDA receptors are overexcited by glutamate in a tonic rather than a phasic manner. This continuous over-activation may lead to neuronal damage by stimulating $\mathrm{Ca}^{2+}$-dependent enzymes related to lipid, protein and nucleic acid metabolism [36]. Increased hippocampal activity is a possible early indicator of AD-related neurodegeneration. In prodromal AD subjects, functional MRI reveals an increase in neural network activities relative to baseline, rather than loss of activity [37]. This may be an attempt to compensate for lower neuron numbers but could also reflect ongoing 'slow excitotoxicity'. Alternatively, loss of inhibitory neurons may disinhibit neurons [38]. Together, these findings indicate that, in $\mathrm{AD}$, neurons and neural networks do not simply 'get silenced' but may instead be hyperactive, and could interfere with processes underlying learning, memory, and other cognitive functions. Interestingly, magnetic resonance spectroscopy reveals significantly lower levels of glutamate in AD brains compared to controls and patients with mild cognitive impairment [39]. This supports the notion that increased excitation or network activity reflects a decreased capacity to cope with existing glutamate levels, rather than a rise in glutamate level per se.

\section{SUMMARY OF AD PATHOGENIC FACTORS}

$A \beta P P / A \beta$

A $\beta P P$ is a member of a family of conserved type I membrane proteins and is present in the postsynaptic density and is involved in maintaining active synapses [40]. It may also be involved in iron transport across membranes [41]. A $\beta P P$ is expressed in neurons and glial cells in the brain, and peripheral tissues including muscle, epithelial tissue, and circulating cells, such as platelets. A $\beta P P$ occurs in three isoforms (A $\beta P P 695$, $A \beta P P 751$, and $A \beta P P 770)$, generated by alternative splicing of exons 7 and 8 [42]. A $\beta P P$ undergoes proteolytic processing by one of two pathways [43]. It can be processed via the non-amyloidogenic pathway mediated by $\alpha$-secretase, of which putative candidates belonging to the family of a disintegrin and metalloprotease (ADAM) have been identified: ADAM9, 
ADAM10, and ADAM17. Enzymatic cleavage by $\alpha$-secretase occurs within the $A \beta$ domain, thereby preventing the generation and release of $A \beta$ peptide. Alternatively, A $\beta P P$ can be a substrate for $\beta$-secretase, releasing an ectodomain ( $\mathrm{SA} \beta \mathrm{PP}$ ), and retaining the last 99 amino acids of A $\beta P P$ (known as C99) within the membrane. The first amino-terminal amino acid of $\mathrm{C} 99$ is the first amino acid of $A \beta$. To eventually release $\mathrm{A} \beta, \mathrm{C} 99$ is subsequently cleaved by the $\gamma$ secretase complex, consisting of PSEN-1 or PSEN-2, nicastrin, anterior pharynx defective, and presenilin enhancer 2 . This cleavage predominantly produces a 40 amino-acid species $A \beta_{40}$, and the more amyloidogenic 42 amino-acid variant $A \beta_{42}$ in a ratio of 10:1. A $\beta_{42}$ aggregates much faster and may be directly related to the pathogenesis of $\mathrm{AD}$ [44]. The presence of $A \beta_{42}$ oligomers (also known as ADDLs) correlates well with the severity of dementia in AD patients [45]. Unlike insoluble fibrils, ADDLs are diffusible molecules that bind a variety of targets thus acting as pathologic ligands [46]. Interaction of ADDLs with synapses results in tau hyperphosphorylation and induction of oxidative stress [47], loss of long-term potentiation [48] and deterioration of synapses [49].

Tau

The microtubule-associated protein, tau, is expressed predominantly in neurons and has been implicated in stabilizing microtubules, regulation of motor-driven axonal transport, and postsynaptic scaffolding [50]. Tau becomes hyperphosphorylated at both physiological and pathological sites in $\mathrm{AD}$, and leads to the formation of toxic aggregates, and eventually neurofibrillary tangles [51]. Aberrant phosphorylation detaches tau from microtubules and affects its microtubule-stabilizing functions, resulting in disruption of communication between the neuronal cell body and processes [52]. A series of recent publications suggests tau to be essential for $A \beta$ to induce downstream toxicity in the pathogenesis of AD [53]. Accordingly, neurons from tau knockout mice show resistance to $A \beta$ toxicity [54]. In addition, crossing A $\beta P P$ transgenic with tau knockout mice ameliorates $A \beta$-induced water-maze learning and memory deficits, increased exploratory locomotor activity and premature mortality, but does not alter high $A \beta$ levels $[55,56]$. Furthermore, tau-knockout neurons are resistant to amino-terminally truncated pyroglutamylated forms of $A \beta$, which are more toxic than $A \beta_{42}$ or $A \beta_{40}$ and possibly involved in initiation of AD pathology [57].
ApoE

ApoE takes up lipids generated after neuronal degeneration and redistributes them to cells requiring lipids for proliferation, membrane repair, or remyelination of new axons [58, 59]. It is well established that the ApoE4 isoform is associated with increased risk of developing AD [60, 61]. Studies in ApoEdeficient mice expressing mutant $\mathrm{A} \beta \mathrm{PP}$ demonstrate that ApoE is required for the formation of fibrillar amyloid plaques [62, 63]. ApoE is associated with amyloid plaques, and lipid-free ApoE3 and ApoE4 can form stable complexes with $\mathrm{A} \beta$, with ApoE4 forming complexes more rapidly and effectively [64]. C-terminally truncated ApoE4 also increases tau phosphorylation and formation of intracellular neurofibrillary tanglelike inclusions in cultured neuronal cells and transgenic mice $[58,59]$. Moreover, ApoE4 is associated with mitochondrial dysfunction in AD patients [65]. ApoE4 fragments target neuronal mitochondria, leading to mitochondrial dysfunction and neurotoxicity $[66,67]$.

\section{Presenilin}

Presenilin polymorphism is associated with an increased risk of sporadic AD. PSEN-2 mutations increase $\mathrm{A} \beta$ generation and oxidative stress [68]. PSEN-1 is a component of the $\gamma$-secretase complex involved in A $\beta P P$ processing. To date, more than 100 pathogenic mutations in the PSEN-1 gene have been identified, and their main biochemical effect is to increase the production of the 'long form' of $A \beta_{42}$ [69]. However, the PSEN-1 mutation insR352 is associated with a frontal temporal dementia phenotype, and decreases $A \beta$ production by inhibiting $\gamma$-secretase cleavage of A $\beta P P[70]$.

\section{AD PATHOGENIC FACTORS AND SLOW EXCITOTOXICITY}

\section{$A \beta P P / A \beta$}

Prolonged activation of extrasynaptic NMDA receptors results in increased expression of neuronal Kunitz protease inhibitory domain (KPI) containing A $\beta P P$ (KPI-A $\beta P P)$, a shift from $\alpha$-secretase to $\beta$-secretasemediated $A \beta P P$ processing, and increased neuronal production of $A \beta$ [71]. $A \beta$ in turn enhances neuronal sensitivity to glutamate and increases the activity of synaptic networks, resulting in excitatory potentials and $\mathrm{Ca}^{2+}$ influx [72]. This could occur in several ways: i) $\mathrm{A} \beta$ increases $\mathrm{Ca}^{2+}$ influx into neurons by 
inducing an oligomeric pore in the membrane, and triggers multiple pathways involving the signal transduction mediators protein kinase A, MAPK, Akt, and cFos [73]. This leads to increased intracellular calcium concentration and glutamate release from axon terminals, and predispose neurons to excitotoxicity [74, 75]. ii) $\mathrm{A} \beta$ oligomers generate reactive oxygen species (ROS) and membrane-associated oxidative stress that impairs the function of ion-motive ATPases and glutamate and glucose transporters [76, 77]. Reduced level of ATPases and glutamate or glucose transporters could lead to depolarization of neurons, calcium influx, and excitotoxicity. iii) $A \beta$ induces activation of NMDA receptors that leads to damage of cellular components and excitotoxicity [78, 79], and hippocampal neurons that express A $\beta$ PP695 show increased damage after glutamate treatment [80]. iv) $A \beta$ and NMDA receptors together induce endoplasmic reticulum (ER) stress that leads to alterations in calcium homeostasis. A $\beta$ induced ER stress and hippocampal dysfunction are prevented by ifenprodil, an antagonist of NMDAR2B (GluN2B) subunits [81]. v) A $\beta$ induces transcriptional and/or translational regulation of the serine racemase gene, and release of low levels of NMDA receptor co-agonists including glutamate and D-serine [82]. vi) $\mathrm{A} \beta$ reduces glutamate uptake at the synaptic cleft $[83,84]$. vii) $A \beta$ affects tau, resulting in changes in neuronal signaling. viii) $A \beta$ induces neuronal insulin resistance and lead to energy deficits that predispose to slow excitotoxicity. ix) A $\beta$ affects mitochondria, resulting in neuronal injury (vi-ix are further discussed below).

\section{Tau}

Tau has also been implicated in excitotoxicity $[53,55]$. KA-induced excitotoxicity leads to transient dephosphorylation of tau, followed by sustained hyperphosphorylation of tau at multiple sites in the mouse brain [85]. The initial dephosphorylation of tau is due to activation of protein phosphatase 2 (PP2A), whereas sustained hyperphosphorylation may result from activation of cyclin-dependent kinase 5 and down-regulation of PP2A during the later phase [85]. Tau is critical in mediating excititoxcity via NMDA receptors [53]. It is important in postsynaptic targeting of the Src kinase Fyn which phosphorylates the NMDA receptor, thus linking it to downstream signaling. Mis-sorting of tau in transgenic mice expressing truncated tau or absence of tau in knockout mice disrupts postsynaptic targeting of Fyn [86]. Decreased expression of tau uncouples NMDA receptor-mediated excitotoxicity and $\mathrm{A} \beta$ toxicity but interestingly, tau overexpression with hyperphosphorylation leads to increased postsynaptic Fyn levels and NMDA receptor phosphorylation [56]. Whether increased mortality in $\mathrm{A} \beta$-forming mice on a tau transgenic background is due to increased excitotoxicity is unknown, but it is clear that reducing endogenous tau levels prevents behavioral deficits in transgenic mice expressing human A $\beta P P$, without altering their high $A \beta$ levels. Tau reduction also protects transgenic and non-transgenic mice against excitotoxicity [56]. Immunization strategies targeting tau ameliorates the tau associated pathology, and could be a potential strategy for treatment of AD [87-89].

ApoE

ApoE attenuates glutamate excitotoxicity in neurons after exposure to NMDA [90]. ApoE treatment has no effect on $\mathrm{H}_{2} \mathrm{O}_{2}$ stimulated glutamate release, but increases the rate of glutamate uptake via high affinity glutamate transporters [91]. Increased ApoE immunoreactivity is observed in astrocytes after excitotoxic injury induced by the glutamate analog, KA [92]. Astrocyte-derived ApoE4 is excitoprotective, while neuronal expression of ApoE4 leads to neuronal death after excitotoxic challenge [93]. ApoE4 is associated with decreased cerebral glucose metabolism in both AD patients and non-demented subjects [94]. This could lead to reduced energy production and failure of ion pumps, and predispose neurons to excitotoxicity.

\section{Presenilin}

PSEN-1 has an effect on the threshold for excitotoxicity. Primary neurons overexpressing mutated PSEN-1 show increased vulnerability to excitotoxic damage. Accelerated neuronal death is also found in the hippocampus of mice overexpressing mutated PSEN-1 after KA induced excitotoxicity [95]. In comparison, mice with mutant PSEN-2 show decreased expression of cyclooxygenases COX-1 and COX-2 in the hippocampus, and reduced seizure activity after KA injury [96].

\section{Kynurenine metabolism}

Decrease in serum levels of tryptophan correlates with level of cognitive impairment, increase in serum kynurenine $(\mathrm{KYN})$, and increase in $\mathrm{KYN} /$ tryptophan ratio in $\mathrm{AD}$ [97]. Moreover, 
acute tryptophan deficiency worsens cognitive functions in AD [98]. Microglial cells degrade KYN into 3-hydroxykynurenine and quinolinic acid. 3Hydroxykynurenine is neurotoxic because of its ability to generate oxidative radicals, while quinolinic acid acts as an agonist for NMDA receptor, and increases tau phosphorylation and neurofibrillary tangle formation [99].

\section{POSSIBLE LINKS BETWEEN NOVEL AD RISK GENES AND SLOW EXCITOTOXICITY}

\section{Clusterin (Table 1)}

Clusterin is a lipoprotein that modulates the membrane attack complex and prevents the inflammatory response associated with complement activation after protein aggregation. Clusterin expression is increased in $\mathrm{AD}$, where it is associated with $\mathrm{A} \beta$ plaques [100]. It co-precipitates with $A \beta$ from cerebrospinal fluid and protects against $A \beta$ neurotoxicity [101]. Clusterin maintains $A \beta$ solubility [102] and the clusterin$\mathrm{A} \beta$ complex is associated with plasma high-density lipoprotein fractions [103]. Many oxidants (e.g., ethanol, tert-butylhydroperoxide or $\mathrm{H}_{2} \mathrm{O}_{2}$ ) induce an immediate secretory clusterin mRNA and protein upregulation [104], which has a protective effect against oxidative stress $[105,106]$. Secretory clusterin localizes to mitochondria and suppresses apoptosis by inhibiting Bax activation [107], modulating p53 stress

Table 1

Role of novel genetic-associated AD risk factors in excitotoxicity

\begin{tabular}{ll}
\hline Gene & Possible mechanism [Reference] \\
\hline Clusterin & A $\beta$ neurotoxicity [101] \\
& A $\beta$ solubility [102] \\
& Oxidative stress [105, 106] \\
& Mitochondria dysfunction [107, 108] \\
& A $\beta$ production [109] \\
PICALM & Iron metabolism [111] \\
& Synaptic dysfunction [112] \\
& A $\beta$ toxicity [113, 114] \\
& Immune response and microglia activation, \\
CR1 & mitochondrial function and oxidative stress \\
& Synaptic dysfunction, seizures [120] \\
& Synaptic dysfunction [121] \\
BIN1 & Lipid metabolism [122] \\
ABCA7 & A $\beta$ secretion [123] \\
& Ca ${ }^{2+}$ homeostasis [124] \\
MS4A & Production of A $\beta$ [127] \\
CD2AP & Inflammation and levels of A $\beta$ [130] \\
CD33 & Glutamate receptor modulation [132, 133] \\
\hline
\end{tabular}

signals and stabilizing the cytosolic Ku70-Bax protein complex [108]. It is therefore possible that alterations in clusterin could lead to an increase in inflammatory response or oxidative stress in neurons.

\section{PICALM}

Single nucleotide polymorphisms (SNPs) in the PICALM gene are associated with AD [109]. In addition, PICALM mRNA is elevated in the frontal cortex of AD patients [110]. PICALM increases A $\beta P P$ internalization and $A \beta$ production. It recruits clathrin and AP-2 (adaptor protein 2) to the plasma membrane, and plays a role in fusion of synaptic vesicles with the presynaptic membrane [111]. Mice deficient in PICALM show dysfunctional haemopoiesis and abnormal iron metabolism [112]. Recent studies using yeast have indicated a role of PICALM in A $\beta$ toxicity $[113,114]$. Changes in adaptor proteins decrease clathin mediated receptor endocytosis and sensitizes neurons to glutamate receptor excitotoxicity [115]. Together, these findings suggest that alterations in PICALM may affect iron metabolism, processing of A $\beta P P$, endocytosis of receptors or exocytosis of neurotransmitters, with effects on neuronal excitation and excitotoxicity.

\section{CR1}

$\mathrm{CR} 1$ is a multifunctional receptor that binds to $\mathrm{C} 1 \mathrm{q}$, other $\mathrm{C}$ opsonins (C4b, $\mathrm{C} 3 \mathrm{~b}, \mathrm{iC} 3 \mathrm{~b})$, and MBL. It is found on circulating monocytes, neutrophils, and $\mathrm{B}$ lymphocytes. C1q binding protein (C1qbp) is located in mitochondria [116]. C1q knockout mice show neuroprotection coupled with attenuated oxidative brain injury, and resistance to oxygen-glucose deprivation. In contrast, post-ischemic exposure to exogenous $\mathrm{C} 1 \mathrm{q}$ increases both mitochondrial ROS production and neuronal injury [117]. C1q receptor overexpression in cells results in caspase-3 activation, mitochondrial dysfunction, and apoptosis [118]. Another study, however, shows that siRNA knockdown of C1qbp increases sensitivity to $\mathrm{H}_{2} \mathrm{O}_{2}$-induced mitochondrial membrane permeability transition and cell death [119]. C1q knockout mice exhibit enhanced synaptic connectivity and frequent seizures [120]. Thus, variants of CR1 may not only induce activation of the adaptive immune response and microglia, but also affect multiple cell signal pathways related to neuronal excitation and excitotoxicity. 


\section{BIN1}

BIN1 encodes members of the BAR (Bin/ amphiphysin/Rvs) adapter family that have been implicated in membrane dynamics, such as vesicle fusion and trafficking, specialized membrane organization, and actin organization. Loss of amphiphysin 1 causes a reduction of BIN1 in the brain, defects in synapticvesicle recycling, learning deficits and increased mortality from rare irreversible seizures [121]. Variants of BIN1 may thus affect the endocytosis/exocytosis cycle in axon terminals, with effects on neuronal excitation and excitotoxicity.

\section{ABCA7}

ABCA7 is a member of the ABC superfamily of transporters that is expressed in cortical neurons, and transports substrates across cell membrane. It is involved in efflux of lipids from cells to lipoprotein particles, and may affect the actions of ApoE and clusterin [122]. ABCA7 regulates A $\beta P P$ processing, inhibits $\mathrm{A} \beta$ secretion, and modulates phagocytosis of apoptotic cells by macrophages mediated through $\mathrm{C} 1 \mathrm{q}$ on the apoptotic cell surface [123]. Variations in ABCA7 may therefore affect the lipid environment of the cell membrane, with effects on membrane receptors and excitotoxicity.

\section{$M S 4 A$}

The MS4A family, including at least 16 paralogues, has transmembrane domains and $\mathrm{N}$ - and C-terminal cytoplasmic domains [124]. MS4A12 is a store operated calcium channel in intestinal cells [125]. This suggests that the protein could have a role in calcium homeostasis.

\section{$C D 2 A P$}

$\mathrm{CD} 2 \mathrm{AP}$ is important in regulating vesicular trafficking to the lysosome, particularly during the formation of multivesicular bodies [126]. The protein is also reported to be involved in modulation of A $\beta P P$ processing and production of $\mathrm{A} \beta$ [127].

\section{CD33}

CD33, also known as Siglec (sialic acid-binding Ig like lectin)-3, encodes a cell-surface receptor on cells of monocytic or myeloid lineage. CD33 controls the innate immune system of the brain and levels of $A \beta$
[128]. The Siglec family of lectins binds sialic acid and regulates the innate immune system via the activation of caspase-dependent and caspase-independent cell-death pathways [129]. It is recently reported that activation of certain Siglecs results in induction of apoptosis. For example, Siglec-8 induces apoptotic cell death in eosinophils, and Siglec-9 triggers apoptosis in neutrophils [128-130]. Although the mechanism of Siglec-mediated apoptosis is not fully understood, recent studies have indicated that Siglec-8 and -9 induce apoptosis largely through ROS dependent processes [128-130].

\section{Ephrins}

Ephrins signal via EphA and EphB receptor tyrosine kinases. Eph/ephrin signals play important roles in boundary formation, cell migration, axon guidance, and growth cone development. Increased EphB2 expression in the dentate gyrus of human A $\beta P P$ transgenic mice reversed deficits in NMDA receptor-dependent long-term potentiation and memory impairments [131]. Ephrin receptors not only initiate new synaptic contacts and recruit/stabilize glutamate receptors at nascent synapses, but also regulate dendritic spine morphology and contribute to longterm changes in synaptic strength and neuroplasticity. EphB receptors are also involved in the regulation of glutamate receptor trafficking, and have been linked to the pathophysiology of $\mathrm{AD}$ [132]. EphrinB rescues primary cortical neuronal cultures from necrotic cell death induced by glutamate excitotoxicity though a mechanism involving EphB receptors and PSEN-1 [133].

\section{POSSIBLE LINKS BETWEEN AD ASSOCIATED METABOLIC CHANGES AND SLOW EXCITOTOXICITY}

\section{Insulin (Fig. 1)}

Brain insulin resistance is an early feature of $\mathrm{AD}$ [134]. This is accompanied by insulin-like growth factor-1 resistance and is closely associated with insulin receptor substrate 1 (IRS-1) dysfunction, potentially triggered by $A \beta$ oligomers. The hippocampal formation and, to a lesser degree, the cerebellar cortex in $\mathrm{AD}$ cases without diabetes, exhibit markedly reduced responses to insulin signaling in the insulin receptor/IRS-1/PI3K signaling pathway with greatly reduced responses to insulin-like growth factor-1. Levels of IRS-1 serine phosphorylation and their 


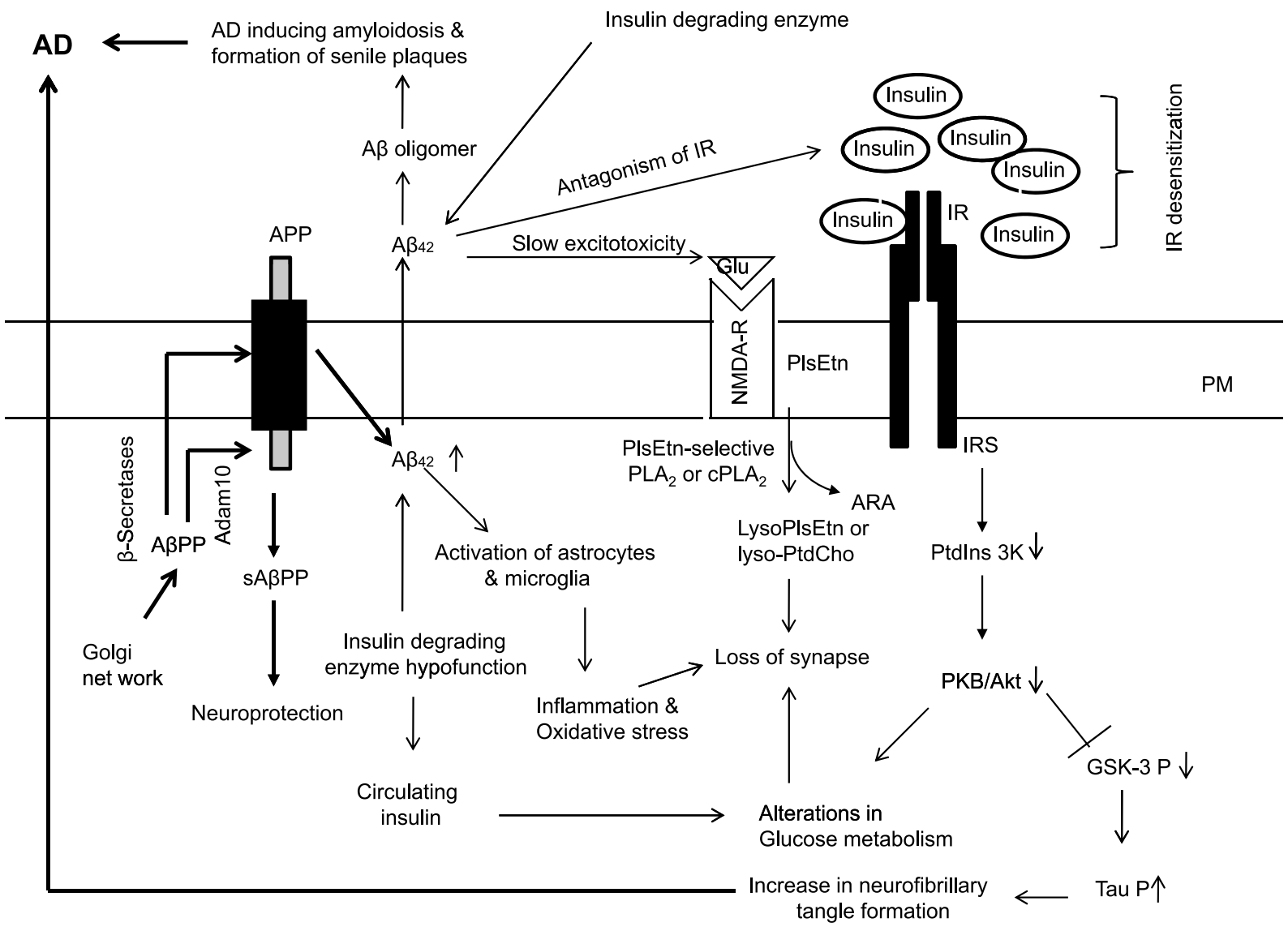

Fig. 1. Abnormal insulin receptor signaling in slow excitotoxicity and increased risk of Alzheimer's disease (AD). Insulin receptor (IR); insulin receptor substrate (IRS); phosphatidylinositol 3 kinase (PtdIns 3K); glycogen synthase kinase 3 (GSK-3); amyloid- $\beta$ protein precursor (AßPP); soluble amyloid- $\beta$ protein precursor (sA $\beta P P)$; amyloid- $\beta$ (A $\beta$ ); serine/threonine protein kinase (Akt); glutamate (Glu); $N$-methylD-aspartate receptor (NMDA-R); plasmalogen-selective phospholipase $\mathrm{A}_{2}$ (PlsEtn-PLA $)$; arachidonic acid (ARA); lyso-phosphatidylcholine (Lyso-PtdCho); plasma membrane (PM); protein kinase B (PKB); upward arrow indicates increase and downward arrow indicates decrease.

activated kinases correlate positively with those of oligomeric $\mathrm{A} \beta$ plaques, and are negatively associated with episodic and working memory [135]. In addition, $\mathrm{A} \beta$ oligomers significantly increase phosphorylation of IRS-1, which triggers its degradation, in cultured hippocampal neurons [136, 137]. These alterations of IRS-1 signaling may, in part, mediate the effects of $A \beta$ on cognition. It is proposed that brain insulin deficiency and resistance induces neuronal death due to trophic factor withdrawal, deficits in energy metabolism, and inhibition of insulin-responsive gene expression, including those required for acetylcholine homeostasis [138]. Decreased glucose utilization as a result of defect in insulin receptor signaling may lead to reduced energy production and failure of ion pumps, with consequences on excitotoxicity. Metabolic inhibition leads to the progressive elevation of extracellular glutamate and aspartate levels in the hippocampus, which correlates with decreased content of EAAT2 and diminished glutamate uptake. Increased phosphorylation and protein content of the NR2B subunit of the NMDA receptor are also observed [139]. High levels of insulin limit $A \beta$ degradation by substrate competition for insulin degrading enzyme (IDE). The latter is a $110-\mathrm{kDa}$ thiol zinc-metalloendopeptidase that cleaves small proteins of diverse sequences, many of which share a propensity to form $\beta$-pleated sheetrich fibrils such as $A \beta$, insulin, glucagon, amylin, atrial natriuretic factor, and calcitonin. A close relationship between IDE with $A \beta$ is supported by recent evidence of decreased IDE expression in the AD brain, and a negative correlation between IDE activity and $A \beta$ content [140-142].

Brain insulin resistance could promote AD onset by raising the level of $A \beta$, tau phosphorylation, oxidative stress, proinflammatory cytokines, advanced glyca- 
tion end products (AGEs), dyslipidemia, and apoptosis [143]. Insulin depletion results in persistent tau phosphorylation in mice [144], while high insulin level as well as complete lack of insulin could cause an imbalance in insulin-regulated tau kinases and phosphatates, and increase in tau phosphorylation [145]. Moreover, high insulin level exacerbates inflammatory responses and increases markers of oxidative stress [146]. Type 2 diabetes mellitus and AD patients show accumulation of AGEs. The latter is a normal process of aging that is accelerated in $\mathrm{AD}$, and involves the non-enzymatic glycosylation and cross-linking of proteins that act through the receptor for AGE (RAGE) to induce oxidative stress, neuronal injury, and neuroinflammation [147].

\section{Mitochondria}

The activities of mitochondrial complex III (ubiquinol-cytochrome c reductase, EC 1.10.2.2) and complex IV (cytochrome c oxidase EC 1.9.3.1) are reduced by $70 \%$ in AD. Inhibition of complex III activity by $60-90 \%$ results in a major increase in the rate of calcium independent glutamate release from synaptosomes depolarized with 4-aminopyridine or $\mathrm{KCl}$ and may be a factor leading to excitotoxic cell death [148]. $\mathrm{A} \beta$ can localize to mitochondria, and this interaction has been suggested to contribute to its cytotoxic effect $[149,150]$. Abnormalities in insulin signaling or mitochondria could lead to generation of ROS (superoxide and hydroxyl anions) and reactive nitrogen species $\left(\mathrm{NO}\right.$ and $\mathrm{ONOO}^{-}$), which may lead to loss of synapses in $\mathrm{AD}$ [151].

\section{Metabolic syndrome}

Metabolic syndrome (MetS) is a condition characterized by central adiposity, dyslipidemia, impaired glucose tolerance, insulin resistance, and hypertension. MetS is a risk factor for the development of AD [138]. Both MetS and AD are accompanied by marked elevation in levels of lipid mediators and cytokines/adipokines [138, 152], which disturbs signaling networks and leads to loss of communication among glutamate, dopamine, and serotonin receptors. MetS and AD are also associated with mitochondrial dysfunction, decrease in ATP production, oxidative stress, and chronic inflammation. Abnormalities in signal transduction networks due to elevated levels of lipid mediators may affect neuronal lipid and protein homeostasis, resulting in neuronal injury $[138,152]$.
Leptin

Leptin is a $16-\mathrm{kDa}$ adipokine that controls energy balance and food intake by acting on brain centers within the hypothalamus that control satiety and body weight. Lower circulating levels of leptin have been reported in patients with $\mathrm{AD}$ [153]. Leptin modulates $\mathrm{A} \beta$ production and tau hyperphosphorylation in vivo and in vitro [154], and enhances NMDA receptor function $[155,156]$. Since synaptic plasticity is the cellular basis of memory formation, it is suggested that leptin may reduce memory loss in animal models of AD. Chronic leptin administration has been reported to reduce $A \beta$ levels in $\mathrm{Tg} 2576$ mice or improve cognitive performance in CRND8 mice models of AD [157-159].

\section{POSSIBLE LINKS BETWEEN AD ASSOCIATED LIPID CHANGES AND SLOW EXCITOTOXICITY}

\section{Phospholipid metabolism (Fig. 2)}

Alterations in membrane lipids play a key role in many neurological and neuropsychiatric disorders including AD. Arachidonic acid is found in high concentrations in brain phospholipids, and is released as a second messenger during neurotransmission, and much more so during neuroinflammation and excitotoxicity. Upregulated brain arachidonic acid metabolism associated with neuroinflammation has been imaged in rodent and AD brains [160, 161]. Increased content of phosphomonoesters and phosphodiesters, which may be the result of increased $\mathrm{cPLA}_{2}$ activity, is also found in the AD brain [162]. Conversely, $\mathrm{PLA}_{2}$ reduction ameliorates cognitive deficits in a mouse model of AD [163]. Low levels of $\mathrm{cPLA}_{2}$ are normally present in the rat forebrain [164], but excitotoxic injury by KA induces neuronal injury and increases $\mathrm{cPLA}_{2}$ mRNA expression in the damaged hippocampus $[165,166]$. The increased cPLA $_{2}$ is immunolocalized to injured neurons and reactive astrocytes and accompanied by elevated levels of the lipid peroxidation product, 4-hydroxynonenal (4$\mathrm{HNE}$ ) in damaged neurons [167]. cPLA 2 inhibitors decrease neuronal injury after KA treatment, indicating an important role of the enzyme in mediating neuronal death after excitotoxic injury [168]. Another isoform of $\mathrm{PLA}_{2}$, sPLA 2 -IIA, is also upregulated in $\mathrm{AD}$ brains compared to non-demented elderly controls. sPLA $_{2}$-IIA-immunoreactive astrocytes are found in association with amyloid plaques in the AD hippocam- 


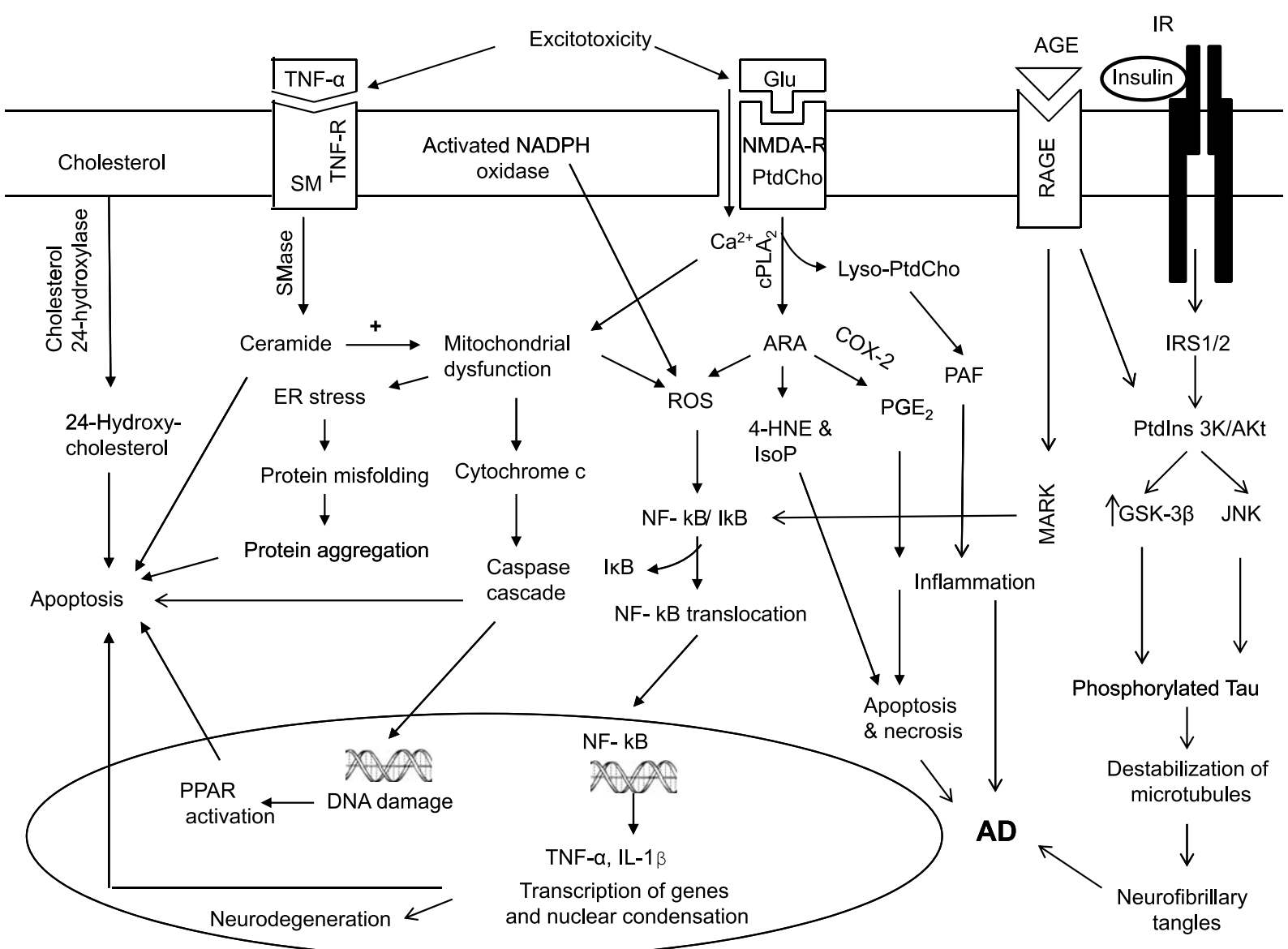

Fig. 2. Hypothetical diagram showing generation of lipid mediators in slow excitotoxicity, oxidative stress, inflammation, and abnormal insulin signaling in Alzheimer's disease (AD). Glutamate (Glu); advanced glycation endproducts (AGE); insulin receptor (IR); receptor for advanced glycation endproducts (RAGE); $N$-methyl-D-aspartate receptor receptor (NMDA-R); tumor necrosis factor receptor (TNF$\mathrm{R})$; sphingomyelin (SM); sphingomyelinase (SMase); cytosolic phospholipase $\mathrm{A}_{2}\left(\mathrm{CPLA}_{2}\right)$; phosphatidylcholine (PtdCho); arachidonic acid (ARA); lyso-phosphatidylcholine (Lyso-PtdCho); reactive oxygen species (ROS); cyclooxygenase-2 (COX-2); 4-hydroxynonenal (4-HNE); prostaglandin $\mathrm{E}_{2}\left(\mathrm{PGE}_{2}\right)$; platelet activating factor $(\mathrm{PAF})$; isoprostane (IsoP); endoplasmic reticulum (ER); nuclear transcription factor-kappaB (NF- $\kappa$ B); tumor necrosis factor- $\alpha$ (TNF- $\alpha$ ); interleukin-1 $\beta$ (IL-1 $\beta$ ); insulin receptor substrate 1/2 (IRS1/2); phosphatidylinositol 3-kinase (PtdIns $3 \mathrm{~K})$; glycogen synthase kinase 3 kinase (GSK-3ß); c-Jun N-terminal kinases (JNK); inhibitor of kappaB (I $\kappa \mathrm{B})$; mitogen-activated protein kinase (MAPK); peroxisome proliferator-activated receptor (PPAR).

pus and inferior temporal gyrus [169]. Expression of sPLA $_{2}$-IIA is induced by oxidative stress and proinflammatory cytokines [170], and increased sPLA 2 activity is detected in the hippocampus after KA injury [171]. sPLA2-IIA is packaged in fusion-competent vesicles and released in a regulated manner after KA receptor stimulation [172]. The enzyme itself induces exocytosis and neurotransmitter release in neuroendocrine cells and neurons [173]. Together, these findings suggest that $\mathrm{SPLA}_{2}$-IIA may play an important role in facilitating neurotransmitter release, with possible effects on excitotoxicity. A related isoform, $\mathrm{SPLA}_{2}$-III, enhances soluble AßPP secretion through its action to increase membrane fluidity and recruitment of A $\beta P P$ at the cell surface [174]. PLA 2 mediates $A \beta$-induced mitochondrial dysfunction [175]. In addition, activation of $\mathrm{PLA}_{2}$ results in the release of fatty acids and lysophospholipids, which are capable of altering membrane microdomains and physical properties. Recent studies have linked aberrant $\mathrm{PLA}_{2}$ activity to oxidative signaling pathways involving NADPH oxidase that underlie the pathophysiology of neurodegenerative diseases [176]. NADPH oxidase generates superoxide by transferring electrons from NADPH inside the cell and coupling these to molecular oxygen to produce superoxide anion (a free radical). 
Both NMDA and oligomeric $A \beta_{1-42}$ could induce ROS production from cortical neurons through activation of NADPH oxidase. ROS derived from NADPH oxidase leads to activation of ERK1/2, phosphorylation of $\mathrm{cPLA}_{2}$, and arachidonic acid release. This effect is prevented by the NMDA receptor antagonists d(-)-2-amino-5-phosphonopentanoic acid and memantine, suggesting the participation of NMDA receptors [177]. Besides arachidonic acid release, ROS induces a more molecularly ordered astrocytic membrane and changes in membrane structure through a mechanism involving phosphorylation of p38 MAPK (mitogen-activated protein kinase) and ERK1/2, and the action of $\mathrm{cPLA}_{2}$ [178]. A $\beta$-induced ROS production, NADPH activation, ERK1/2 activation, and cPLA $_{2}$ phosphorylation are inhibited by an antibody to RAGE in cultured brain endothelial cells and astrocytes. Together, these findings indicate the importance of AGE receptors, NADPH, and ERK in mediating oxidative stress and $\mathrm{CPLA}_{2}$ activation in $\mathrm{AD}$ [179].

$\mathrm{cPLA}_{2}$ and $\mathrm{SPLA}_{2}$ release arachidonic acid from the $s n-2$ position of glycerophospholipids. Arachidonic acid can undergo lipid peroxidation and decompose to yield the toxic product 4-HNE. The latter is very reactive and forms adducts with membrane proteins, including those crucial for maintaining ATP levels, membrane potential, and extracellular glutamate levels [180]. Decreased activity of glucose transporter and $\mathrm{Na}^{+} / \mathrm{K}^{+}$ATPase affects ATP production and the ability of ion pumps to maintain ionic balance in neurons, while decreased activity of glutamate transporters results in reduced ability to maintain extracellular glutamate concentration, and predispose neurons to excitotoxicity $[181,182]$. cPLA 2 inhibitors prevent an increase in 4-HNE, and significantly reduces neuronal injury after KA-induced excitotoxic injury [168]. Further metabolism of arachidonic acid to eicosanoids and conversion of lysophospholipid to platelet activating factor may contribute to the initiation and intensification of neuroinflammation. Arachidonic acid is metabolized to prostaglandins by COX enzymes. COX-mediated neuronal injury may be due to downstream effects of one or more prostaglandins (PGs) including PGE2, PGD2, PGF2 $\alpha$, PGI2 (prostacylin), and TXA2 (thromboxane) that effect cellular changes through activation of specific $\mathrm{PG}$ receptor subtypes and second messenger system. Inhibition of COX activity with non-steroidal anti-inflammatory drugs reduces inflammation and $A \beta$ accumulation in a mouse model of $\mathrm{AD}$ [183]. The other product of $\mathrm{PLA}_{2}$ action, lysophospholipids, is not only converted into proin- flammatory platelet activating factor but acts as a detergent at the cell membrane, leading to disturbance in ion homeostasis [184]. Lysophospholipids may also function as signaling molecules [185]. Some lysophospholipids, such as lysophosphatidylinositol, trigger an increase in intracellular calcium and exocytosis in PC12 cells, with possible consequences on excitotoxicity [186].

A third isoform of $\mathrm{PLA}_{2}$, calcium-independent $\mathrm{PLA}_{2}$ (iPLA ${ }_{2}$ ), is decreased in AD brain [187]. iPLA $_{2}$ activity of platelets from AD patients are also markedly lower than that of control subjects [188]. About five-fold higher mRNA expression of iPLA $_{2}$ than $\mathrm{CPLA}_{2}$ are found in the normal brain [189], and the enzyme is essential for the release of docosahexaenoic acid (DHA), which has anti-inflammatory and anti-oxidative stress effects. Neuroprotective actions of DHA may result from downregulation of AMPA receptors in hippocampal membranes, and through the generation of resolvins and protectins, which have neuroprotective properties [190-192]. A recent study shows that iPLA $_{2} \gamma$ deficiencies accentuate AMPA receptor destabilization and tau phosphorylation, which suggests that this isoform may be a therapeutic target for tau-related disorders, including AD [193]. Together, the results indicate activation or upregulation of $\mathrm{cPLA}_{2}$ and $\mathrm{sPLA}_{2}$, and increase in arachidonic acid and phospholipid metabolites that aggravate neuronal injury; but downregulation of iPLA $_{2}$, and decrease in DHA and metabolites that reduce neuronal injury, in brain tissue of $\mathrm{AD}$.

\section{Cholesterol (Fig. 2)}

There are conflicting reports on the role of cholesterol in $\mathrm{AD}$, although most studies point to an association between cholesterol with $\mathrm{AD}$ pathogenesis. While a link is known between serum cholesterol and brain levels of $\mathrm{A} \beta$ in the AD brain [194], there have been few studies that address the question of brain cholesterol levels in areas of ongoing damage within the $\mathrm{AD}$ brain. A recent study using an original method to quantify cholesterol distribution using time-of-flight secondary ion mass spectrometry imaging shows that cholesterol overload appears a new and independent alteration of AD cerebral cortex. In this study, the mean cholesterol signal was found to be higher in the lower half of the cortex in AD samples, compared to controls [195]. Studies on the effect of high cholesterol or 27-hydroxycholesterol on human neuroblastoma SH-SY5Y cells and organotypic slices 
from rabbit hippocampus indicate that cholesterol and 27-hydroxycholesterol produce AD-like pathology by increasing $A \beta$ production and triggering apoptotic cell death [196]. The C99 transmembrane carboxylterminal domain of A $\beta P P$ is cleaved by $\gamma$-secretase to release $A \beta$, and nuclear magnetic resonance and electron paramagnetic resonance spectroscopy of C99 reveals a binding site for cholesterol, providing a mechanistic explanation to how cholesterol promotes amyloidogenesis [197]. In situ Raman analysis of tissue sections in $\mathrm{AD}$ mice provides distinct spectra useful for distinguishing AD from normal tissues, and biochemical changes including deposition of $A \beta$, increase in cholesterol, and hyperphosphorylated tau are detected in hippocampal tissues from AD mice [198].

A large increase in total cholesterol content of up to two fold is detected by GC-MS in the rat hippocampus, 1-2 weeks after excitotoxic injury induced by KA. This is accompanied by early increases in cholesterol biosynthetic precursors, lanosterol, desmosterol, and 7-dehydrocholesterol at 1 day post-KA injection, presumably reflecting increased neuronal biosynthesis in areas of ongoing injury. In contrast, levels of precursors are reduced in the mature glial scar. Elevated levels of potentially toxic cholesterol oxidation products or oxysterols such as 24-hydroxycholesterol, $7 \beta$-hydroxycholesterol, and 7-ketocholesterol are also detected from days to weeks after injury, and loss of expression of the cholesterol transporter, ABCA1 is detected in neurons [199-201]. Together, these findings indicate profound changes in brain cholesterol metabolism in areas of ongoing damage, and increased formation of cholesterol oxidation products in degenerating brain tissue after excitotoxicity [202].

Cholesterol stimulates the insertion of A $\beta P P$ into phospholipid monolayers, and directly or indirectly promotes $A \beta P P$ processing in favor of insoluble $A \beta$ deposition [203]. However, it remains controversial whether cholesterol enhances or reduces $A \beta$ polymerization, and the association between cholesterol homeostasis and AD may not be simply through the regulation of $A \beta$ fibrillogenesis [203, 204]. The level of cholesterol in the cell membrane has a prominent effect on trafficking of synaptic vesicles; reduction in cholesterol impairs vesicle movement, while increased cholesterol facilitates vesicle movement and exocytosis of neurotransmitters in neuroendocrine cells [205]. Together, these findings suggest that increased brain cholesterol level after neuronal injury could serve as a positive feedback cycle to further propagate slow excitotoxicity.

\section{Cholesterol oxidation products/oxysterols}

$\mathrm{A} \beta$ and $\mathrm{A} \beta \mathrm{PP}$ have been shown to oxidize cholesterol to form 7 $\beta$-hydroxycholesterol and cholesterol-derived aldehydes that are pro-apoptotic at nanomolar concentrations. 7 $\beta$-hydroxycholesterol blocks the secretion of soluble A $\beta P P$ from cultured rat hippocampal neurons [206]. In addition, cholesterol-derived aldehydes accelerate the early stages of amyloidogenesis through modification of $\mathrm{A} \beta$ and promotion of Schiff base formation [207]. As noted above, significant increase in cholesterol oxidation products is found in damaged hippocampal tissues after KA treatment. This could lead to further injury through sustained increase of cytosolic-free calcium, and dephosphorylation of the Bcl-2-associated death promoter protein. PC12 cells exposed to 7-ketocholesterol show nuclear damage, decrease in mitochondrial transmembrane potential, cytosolic accumulation of cytochrome c, activation of caspase-3, and oxidative stress [208, 209]. Moreover, increased intracellular calcium and exocytosis is observed in cells after treatment with cholesterol oxidation products [210]. Together, these findings indicate that increases in cholesterol oxidation products could induce a rise in intracellular calcium concentration and exocytosis, with possible effects on excitotoxicity.

\section{Ceramides (Fig. 2)}

Accumulation of ceramide and perturbation of sphingomyelin metabolism are key events in the dysfunction and degeneration of neurons in AD [211]. Marked increase in levels of ceramide, and increased expression of acid sphingomyelinase (ASMase) and acid ceramidase are found in the AD brain [212, 213]. Significant correlations are also observed between brain ASMase activity and levels of $A \beta$ and hyperphosphorylated tau protein. Treatment of neural cell cultures with $\mathrm{A} \beta$ oligomers not only activates ASMase, but also increases ceramide [214]. Ceramide induces oxidative stress, insulin resistance, impairment in energy metabolism, and apoptotic cell death [214, 215]. Increased ceramide accumulation occurs in degenerating brain tissues after KA injury [216], partly due to increased expression of serine palmitoyltransferase, the first enzyme in the ceramide biosynthetic pathway, in reactive astrocytes [217]. Treatment of hippocampal slice cultures with the SPT inhibitor ISP-1 (myriocin) or L-cycloserine modulates the increases in 16:0, 18:0, and 20:0 ceramide species, and reduces 
KA-induced cell death [217]. Several short chain- and $\mathrm{C} 18$ ceramides produce an increase in intracellular calcium, and enhance exocytosis in PC12 cells [218]. Together, these findings indicate increased ceramide levels in $\mathrm{AD}$, and a potential role of ceramides in neurotransmitter release and excitotoxicity.

\section{Neurosteroids}

Reduction of neurosteroids, which are derived from cholesterol in the brain, has been found in sporadic AD. Neurosteroids include compounds such as prenenolone, DHEA, and estrogen that are endogenously produced in the brain, and provide protection from excessive neuronal excitation [219]. Decreased level of pregnenolone is found in the rat hippocampus after KA injury, and may increase the vulnerability of remaining neurons to excitotoxicity [220].

\section{POSSIBLE LINKS BETWEEN AD ASSOCIATED GLIAL CHANGES AND SLOW EXCITOTOXICITY}

\section{Microglia}

Senile plaques in AD contain large numbers of reactive microglia/macrophages in addition to potentially neurotoxic aggregates of $A \beta$ [221]. These glial cells are activated by glutamate excitotoxicity in a number of ways, including the release of proinflammatory cytokines, nitric oxide, reactive oxygen intermediates, proteinases, and complement proteins [222, 223]. Microglia/macrophages are capable of generating an 'oxidative burst' to produce superoxide radicals, which react with nitric oxide (NO) to produce peroxynitrite. Superoxide or peroxynitrite can then react with membrane lipids to affect the function of glutamate receptors, with effects on excitotoxicity [224, 225]. In addition, NO overproduction by inducible NO synthase compromises cellular signaling via aberrant protein S-nitrosylation. This can contribute to progression of $\mathrm{AD}$ and neuronal cell injury through alterations in mitochondrial dynamics and synapse loss, and ER protein folding [226, 227]. Microglia may also cause a rise in extracellular glutamate levels through the cystine-glutamate antiporter system, which facilitates the cellular intake of cystine in exchange for release of glutamate. Increased expression of the cystineglutamate antiporter is found in reactive microglia in a mouse model of $\mathrm{AD}$, and its inhibition leads to reduced $A \beta$ neurotoxicity [228]. Recent studies also show that microglia express NMDA receptors, and it is possible that these cells may react to high levels of extracellular glutamate, resulting in propagation of neuronal damage [229]. NMDA receptor stimulation triggers microglia activation and secretion of factors that induce cell death of cortical neurons, and in turn, damaged neurons activate microglial NMDA receptors to aggravate neurologic disease [230].

\section{Astrocytes}

Astrocytes are activated in $\mathrm{AD}$ and contribute to an inflammatory cascade. By transforming from a basal to a reactive state, astrocytes neglect their neurosupportive functions including uptake of glucose and release of lactate; uptake of glutamate and release of glutamine; and uptake of glutathione precursors and release of glutathione. This results in disruptions in synaptic connectivity, imbalance in neurotransmitter homeostasis, and neuronal death through increased excitotoxicity $[231,232]$. Oxidative stress induced by $A \beta$ leads to a reduction in glutamate transporter activity, with EAAT2 being affected more than EAAT1. A $\beta$ induces activation of MAP kinases, ERK, p38, and c-Jun $\mathrm{N}$-terminal kinase, and these pathways differentially modulated the glutamate transporters activity/levels [84]. The effect of $A \beta$ astrocyte glutamate transporters and uptake is dependent on adenosine $2 \mathrm{~A}$ receptors (A2AR). A $\beta$ enhances expression and density of astrocytic A2AR and decreases EAAT1 and EAAT2 expression in astrocytes from wild type, but not A2AR knockout mice [233]. Expression of astrocyte EAAT2 in the hippocampus is reduced in ApoE mutant mice, suggesting inefficient glutamate uptake by astrocytes [234]. Together, these findings suggest that glial cells could contribute to excitotoxicity by increasing glutamate release in the case of microglia, or through reducing glutamate uptake in reactive astrocytes.

\section{POSSIBLE LINKS BETWEEN AD ASSOCIATED IRON CHANGES AND SLOW EXCITOTOXICITY}

Iron accumulation occurs in and around $A \beta$ plaques and neurofibrillary tangles in AD. This is accompanied by abnormal interactions between iron transportor binding proteins (transferrin and ferritin) and their regulatory elements, and disruption in the sequestration and storage of iron by ferritin [235, 236]. High levels of iron enhance amyloidogenic processing of 
A $\beta P P ~[237]$, promote phosphorylation of tau protein [238], and increase formation of ROS [239]. Iron may promote the formation of free radicals by $A \beta$, via the methionine 35 residue of $A \beta$ [240]. A late increase in iron level is detected in the degenerating hippocampus after KA induced excitotoxicity, using the quantitative method of nuclear microscopy [241]. In addition, there is a shift in the oxidation state of iron, with more cells becoming positive for ferrous iron at a later time (months). The latter is a state of iron that is particularly effective in catalyzing free radical reactions [242]. The level of iron binding protein, ferritin, increases in tandem with the increase in iron up to one month postKA lesion, but a later stage, there is decreased ferritin expression which could lead to more iron being present in an unbound form, that is capable of catalyzing free radical reactions [243]. Increased mRNA and protein expression of a ferrireductase, duodenal cytochrome B (DCYTB) (Ong WY, unpublished observations) and increased protein expression of iron transporter, divalent metal transporter-1 (DMT1) are found in reactive astrocytes and their end-feet around brain capillaries after KA injury [244, 245]. Increased expression of these proteins at the blood-brain interface suggests that they could be important in brain iron transport. A recent study shows that uptake of dietary iron is much higher than previously thought. Although only a very small amount of dietary iron entered the brain, this amount is considerable relative to the total brain iron content $(9.19 \pm 0.71 \%)$, and is comparable in percentage uptake to other tissues [246].

Increase in brain iron could also occur as a result of hypercholesterolemia, probably due to generalized damage to endothelial cells, including those at the blood-brain barrier. New Zealand white rabbits that were treated with a high cholesterol diet for 8 weeks show increased number of iron laden macrophages and oligodendrocytes around microvessels in the cerebral cortex and subcortical white matter [247]. Similar changes are found in the liver, where hypercholesterolemia is associated with elevated levels of oxidative stress and increased number of iron-laden macrophages around microvessels [248]. It is postulated that high levels of serum cholesterol may subtly affect endothelial cells, resulting in increased transport of iron into the brain [247, 249]. Increased iron leads to free radical formation via the Haber-Weiss or Fenton reactions and damage to cellular components. Indeed, many studies show that iron is very epileptogenic and has great potential to induce neuronal excitation, with consequences for excitotoxicity [250].

\section{TREATMENT STRATEGIES FOR AD TARGETING SLOW EXCITOTOXICITY}

\author{
Memantine (Fig. 3)
}

Memantine is a non-competitive NMDA receptor antagonist that has been approved by the FDA for treatment of patients with moderate to severe $\mathrm{AD}$ [251]. It slows the progression of mild and moderate-to-severe $\mathrm{AD}$ and possibly vascular dementia, though its effects are limited [252]. Memantine acts as a non-competitive low-affinity modulator of NMDA receptors, and results in prevention of neuronal necrosis induced by glutamatergic calcium neurotoxicity, but not neuronal apoptosis resulting from oxidative stress [253]. It blocks excessive NMDA receptor activity, while leaving normal function relatively intact [254]. Memantine does not alter the conformation or internalization of $A \beta_{42}$ and is unable to attenuate $A \beta$-induced potentiation of extracellular glutamate levels, but protects neurons by attenuating tau-phosphorylation and its associated signaling mechanisms [255]. Memantine could also have a beneficial effect on mitochondrial function by modulating the reduction in mitochondrial membrane potential and mitochondrial reductase activity after excitotoxic injury [256]. Memantine has good tolerability, low side-effect profiles, and a positive, though limited, therapeutic impact in moderate to severe $\mathrm{AD}$ patients, alone, and in conjunction with donepezil [257, 258]. Low levels of memantine have been found to promote neuroplasticity and memory formation [259, 260]. More recently, second generation memantines (NitroMemantine) have been synthesized, which use memantine as a homing signal to target NO to hyperactivated NMDA receptors, in order to avoid systemic side-effects of NO such as hypotension. The NitroMemantines have enhanced neuroprotective efficacy in vitro, and in animal models of neurological disorders [261, 262].

\section{Metformin (Fig. 3)}

Metformin is a biguanide anti-hyperglycaemic drug that is used to treat type 2 diabetes mellitus. Metformin suppresses gluconeogenesis and enhances glucose uptake and insulin sensitivity. Metformin protects against neurological complications of type 2 diabetes mellitus, including cognitive impairment and cerebral vascular disease [263]. Recently, metformin has been used in a clinical trial for $\mathrm{AD}$, and it is reported that this drug can produce beneficial effects in AD patients [264]. When administered with insulin, metformin 
<smiles>CC12CC3CC(C)(C1)CC([O-])(C3)C2</smiles>

Memantine<smiles>CC12CC3CC(N)(C1)CC([N+](=O)[O-])(C3)C2</smiles>

Nitromemantine<smiles>CN(C)C(N)NC(=N)N</smiles>

Metformin<smiles>COc1cc(/C=C/C(=O)CCc2ccc(/C=C/C(=O)CC(=O)/C=C/c3ccc(O)c(OC)c3)cc2OC)ccc1O</smiles><smiles>O=C([O-])CC(O)CC(O)CCn1cc(C(=O)Nc2ccccc2)c(-c2ccccc2)c1-c1ccc(F)cc1</smiles>

Atorvastatin<smiles>Oc1c(I)cc(Cl)c2cccnc12</smiles>

Clioquinol

Fig. 3. Chemical structures of therapeutic agents used for the treatment of AD in animal and cell models.

provides significant neuroprotection in that A $\mathrm{APP}$ $\mathrm{A} \beta$ levels including $A \beta P P-A \beta$ neuritic plaques, and oligomeric $A \beta P P-A \beta$-mediated downregulation of the insulin receptor are reduced [265]. Metformin plus insulin may benefit patients in the early stages of AD by significantly improving cognitive performance and slowing the rate of neurodegeneration [146]. Recently, an anti-diabetes agent, exendin-4, has also been reported to prevent impaired $A \beta$-induced neuronal pathologies such as axonal transport in animals [266].

\section{Statins}

Statins or cholesterol lowering drugs reduce cholesterol levels in the blood. Lovastatin protects cortical neurons in a concentration-dependent manner against glutamate-mediated excitotoxicity. Lovastatin significant reduces KA-induced neuronal damage in vivo and in vitro [198, 267]. It increases TNF receptor 2 (TNFR2) expression and protects neurons against ischemic or excitotoxic insults [268], and may have therapeutic potential in the treatment of neurodegenerative diseases involving excitotoxicity [198, 267]. Besides lovastatin, another brain permeable statin, simvastatin, is also effective in neuroprotection in KA excitotoxicity- and mouse AD models. Simvastatin (3-6 months, $40 \mathrm{mg} / \mathrm{kg} / \mathrm{d}$ ) rescues cerebrovascular reactivity, basal endothelial nitric oxide synthesis, and activity-induced neurometabolic and neurovascular coupling in adult ( 6 months) and aged (12 months) transgenic mice overexpressing A $\beta P P$ mutations, and restores short- and long-term memory in adult $\mathrm{AD}$ mice [267, 269].

Besides a direct effect on modulation of neuronal cholesterol biosynthesis, it is possible that reduction of serum cholesterol by statins could have a beneficial effect on endothelial cells at the blood-brain-barrier. We postulate that one of the beneficial effects of statins, besides reducing excessive brain cholesterol biosynthesis after excitotoxic damage, is reduction of damage at the blood brain interface, thus preventing excessive influx of metals, and oxidative stress in the brain [249]. 


\section{Acetylcholinesterase inhibitors}

The mainstay of drug treatment for $\mathrm{AD}$ at the moment is acetylcholinesterase (AChE) inhibitors, which act to increase the level of acetylcholine in the brain. Donepezil, a potent AChE inhibitor that is used for the treatment of $\mathrm{AD}$, shows neuroprotective effects against $A \beta_{42}$ toxicity in cultured rat septal cholinergic neurons [270]. Donepezil also decreases neuronal damage in cultured neurons after NMDA treatment [271]. The level of NR1 on the cell surface and glutamate mediated $\mathrm{Ca}^{2+}$ entry is reduced by donepezil, which might contribute to its neuroprotective effects [272]. Another AChE inhibitor, tacrine, reverses declines in mitochondrial membrane potential, ATP production, and neuronal cell death induced by glutamate [273].

\section{Curcumin}

Curcumin, a hydrophobic polyphenol, is the yellow pigment in the Indian spice turmeric (curry powder), derived from the rhizome of the herb Curcuma longa. Epidemiological studies in India have indicated that consumption of curcumin in the daily diet is associated with significant reduction in the prevalence of $\mathrm{AD}$ [274]. Curcumin can exert anti-inflammatory, antioxidant, and neuroprotective actions; it is reported to decrease oxidative damage and $A \beta$ deposition in a mouse model of $A D$, and reverse $A \beta$-induced cognitive deficits and neuropathology in rats [275]. Curcumin protects cultured neurons against glutamate-induced excitotoxicity by a mechanism requiring TNFR2 activation, suggesting that therapeutic approaches against cognitive decline designed to selectively enhance TNFR2 signaling are likely to be more beneficial than use of anti-inflammatory drugs per se [276]. This action of curcumin is very similar to one proposed for statins, noted above.

\section{Antioxidants}

Increased oxidative stress in brain tissue is an important feature in the pathophysiology of AD [277-279]. Conversely, clinical studies have shown antioxidant treatment to be effective in ameliorating symptoms of the disease. For instance, treatment with $\alpha$-tocopherol reduces neuronal damage and slows the progression of $\mathrm{AD}$ [280]. Some traditional herbal antioxidants also exhibit potential for AD treatment. Apocynin, a constituent of the Himalayan medicinal herb Picrorhiza kurroa, has been reported to exhibit anti-AD effects through NADPH-oxidase inhibition to suppress ROS and reactive nitrogen species [281].

\section{Metal chelators, e.g., clioquinol}

Clioquinol is an antibiotic with strong metal chelating properties. It crosses the blood-brain barrier and binds $\mathrm{Cu}^{2+}, \mathrm{Zn}^{2+}$, and $\mathrm{Fe}^{3+}$ ions that are critically involved in $A \beta$ aggregation and toxicity [282]. Clioquinol reverses impairment in working memory, significantly decreases $A \beta$ plaque burden, and attenuates astrocytosis in the cortex and hippocampus in a mouse model of AD [282].

\section{CONCLUSION AND PERSPECTIVE}

There is a large body of evidence that supports the role of $A \beta$ in slow excitotoxicity in the pathogenesis of $\mathrm{AD}$. Possible mechanisms by which $\mathrm{A} \beta$ could cause slow excitotoxicity may involve the ability of $A \beta$ to reduce glutamate uptake or induce glutamate release, and several existing risk factors for $\mathrm{AD}$ have been found to have effects on excitotoxicity. Induction of $A \beta$-mediated slow excitotoxicity in the pathogenesis of $\mathrm{AD}$ is supported by recent studies demonstrating interactions among glycerophospholipid-, sphingolipid-, and cholesterolderived lipid mediators. Moreover, the low affinity open channel NMDA receptor antagonist, memantine, slows the progression of AD. Thus, growing evidence supports the view that $A \beta$-mediated slow excitotoxicity may be critically involved in neurodegeneration in AD. More recent evidence supports that tau, the second hallmark protein in $\mathrm{AD}$, is also directly involved in excitotoxicity. In particular, it is necessary for $A \beta$ to mediate its toxicity, and hence, tau depletion or truncation protects mice from $A \beta$-induced deficits, including memory deficits. Therefore, slow excitotoxicity in AD may be orchestrated by $A \beta$ and tau, and new therapeutic strategies should consider this interplay. Further studies will reveal the exact molecular mechanisms that tau contributes to in the post-synapse.

Many of the other novel genetic risk factors for sporadic $\mathrm{AD}$ and cellular responses that have been shown to be involved in AD may also contribute to slow excitotoxicity. Here, future research will reveal the exact molecular links. As discussed, possible approaches including maintenance of insulin signaling and energy metabolism, modulation of glial cell function, inhibition of iron accumulation and neuroinflammation, modulation of lipid mediators, and reducing oxidative stress may hold promise in the future to block slow 
excitotoxicity. It is hoped that better understanding of the molecular links between pathogenic factors and slow excitotoxicity could inform our understanding of the disease, and pave the way toward new therapeutic strategies for $\mathrm{AD}$.

\section{ACKNOWLEDGMENTS}

This work was supported by the National Medical Research Council of Singapore and the National Health and Medical Research Council of Australia. L.M.I. is a National Health and Medical Research Council Senior Research Fellow, Australia.

Authors' disclosures available online (http://www.jalz.com/disclosures/view.php?id=1680).

\section{REFERENCES}

[1] Farooqui AA (2010) Neurochemical Aspects of Neurotraumatic and Neurodegenerative Diseases, Springer, New York.

[2] Farooqui AA (2010) Neurochemical aspects of neuroinflammation in brain. In Molecular Aspects of Neurodegeneration and Neuroprotection, Farooqui AA, Farooqui T, eds. Bentham Science Publishers Ltd.

[3] Arlt S, Beisiegel U, Kontush A (2002) Lipid peroxidation in neurodegeneration: New insights into Alzheimer's disease. Curr Opin Lipidol 13, 289-294.

[4] Butterfield DA (2002) Amyloid beta-peptide (1-42)-induced oxidative stress and neurotoxicity: Implications for neurodegeneration in Alzheimer's disease brain. A review. Free Radical Res 36, 1307-1313.

[5] Kontush A (2001) Amyloid-beta: An antioxidant that becomes a pro-oxidant and critically contributes to Alzheimer's disease. Free Radic Biol Med 31, 1120-1131.

[6] de la Torre JC (2010) Vascular risk factor detection and control may prevent Alzheimer's disease. Ageing Res Rev 9, 218-225.

[7] Bertram L, Tanzi RE (2009) Genome-wide association studies in Alzheimer's disease. Hum Mol Genet 18, R137-R145.

[8] Guerreiro RJ, Hardy J (2011) Alzheimer's disease genetics: Lessons to improve disease modelling. Biochem Soc Trans 39, 910-916.

[9] Choi DW (1988) Glutamate neurotoxicity and diseases of the nervous system. Neuron 1, 623-634.

[10] Olney JW, Wozniak DF, Farber NB (1997) Excitotoxic neurodegeneration in Alzheimer disease. New hypothesis and new therapeutic strategies. Arch Neurol 54, 1234-1240.

[11] Farooqui AA, Horrocks LA (1991) Excitatory amino acid receptors, neural membrane phospholipid metabolism and neurological disorders. Brain Res Rev 16, 171-191.

[12] Farooqui AA, Horrocks LA (1994) Excitotoxicity and neurological disorders: Involvement of membrane phospholipids. Int Rev Neurobiol 36, 267-323.

[13] Phillis JW, Horrocks LA, Farooqui AA (2006) Cyclooxygenases, lipoxygenases, and epoxygenases in CNS: Their role and involvement in neurological disorders. Brain Res Rev 52, 201-243.
[14] Oka A, Belliveau MJ, Rosenberg PA, Volpe JJ (1993) Vulnerability of oligodendroglia to glutamate: Pharmacology, mechanisms, and prevention. J Neurosci 13, 1441-1453.

[15] Matute C, Domercq M, Sánchez-Gómez MV (2006) Glutamate-mediated glial injury: Mechanisms and clinical importance. Glia 53, 212-224.

[16] Auger C, Attwell D (2000) Fast removal of synaptic glutamate by postsynaptic transporters. Neuron 28, 547-558.

[17] Farooqui AA, Ong WY, Horrocks LA (2008) Neurochemical Aspects of Excitotoxicity, Springer, New York.

[18] Beal MF (1992) Mechanisms of excitotoxicity in neurologic diseases. FASEB J 6, 3338-3344.

[19] Novelli A, Reilly JA, Lysko PG, Henneberry RC (1988) Glutamate becomes neurotoxic via the $\mathrm{N}$-methyl-D-aspartate receptor when intracellular energy levels are reduced. Brain Res 451, 205-212.

[20] Zeevalk GD, Nicklas WJ (1990) Chemically induced hypoglycemia and anoxia: Relationship to glutamate receptor-mediated toxicity in retina. J Pharmacol Exp Ther 253, 1285-1292.

[21] Beal MF, Swartz KJ, Hyman BT, Storey E, Finn SF, Koroshetz W (1991) Aminooxyacetic acid results in excitotoxin lesions by a novel indirect mechanism. J Neurochem 57, 1068-1073.

[22] Storey E, Hyman BT, Jenkins B, Brouillet E, Miller JM, Rosen BR, Beal MF (1992) 1-Methyl-4-phenylpyridinium produces excitotoxic lesions in rat striatum as a result of impairment of oxidative metabolism. J Neurochem 58, 1975-1978.

[23] Farooqui AA, Horrocks LA (2006) Phospholipase $A_{2-}$ generated lipid mediators in the brain: The good, the bad, and the ugly. Neuroscientist 12, 245-260.

[24] Farooqui AA, Ong WY, Farooqui T (2010) Lipid Mediators in the nucleus: Their potential contribution to Alzheimer's disease. Biochim Biophys Acta 1801, 906-1016.

[25] Casado M, Ascher P (1998) Opposite modulation of NMDA receptors by lysophospholipids and arachidonic acid: Common features with mechanosensitivity. J Physiol 513, 317-330.

[26] Iwamoto T, Yamada Y, Hori K, Watanabe Y, Sobue K, Inui M (2004) Differential modulation of NR1-NR2A and NR1-NR2B subtypes of NMDA receptor by PDZ domaincontaining proteins. J Neurochem 89, 100-108.

[27] Delint-Ramirez I, Fernandez E, Bayes A, Kicsi E, Komiyama NH, Grant SG (2010) In vivo composition of NMDA receptor signaling complexes differs between membrane subdomains and is modulated by PSD-95 and PSD-93. J Neurosci 30, 8162-8170.

[28] Simons K, Ikonen E (2000) How cells handle cholesterol? Science 290, 1721-1726.

[29] Farooqui AA, Horrocks LA (2007) Glycerophospholipids in the Brain: Phospholipases $A_{2}$ in Neurological Disorders, Springer, New York.

[30] Masliah E, Mallory M, Alford M, DeTeresa R, Hansen LA, McKeel DW Jr., Morris JC (2001) Altered expression of synaptic proteins occurs early during progression of Alzheimer's disease. Neurology 56, 127-129.

[31] Farooqui AA, Ong WY, Horrocks LA (2003) Plasmalogens, docosahexaenoic acid and neurological disorders. Adv Exp Med Biol 544, 335-354.

[32] Farooqui T, Farooqui AA (2009) Aging: An important factor for the pathogenesis of neurodegenerative diseases. Mech Ageing Dev 130, 203-215.

[33] Terry RD, Masliah E, Salmon DP, Butters N, DeTeresa R, Hill R, Hansen LA, Katzman R (1991) Physical basis of 
cognitive alterations in Alzheimer's disease: Synapse loss is the major correlate of cognitive impairment. Ann Neurol 30, $572-580$

[34] De Felice FG, Vieira MN, Bomfim TR, Decker H, Velasco PT, Lambert MP, Viola KL, Zhao WQ, Ferreira ST, Klein WL (2009) Protection of synapses against Alzheimer'slinked toxins: Insulin signaling prevents the pathogenic binding of Abeta oligomers. Proc Natl Acad Sci U S A 106, 1971-1976.

[35] Farooqui AA, Ong WY, Horrocks LA (2003) Stimulation of lipases and phospholipases in Alzheimer disease. In Nutrition and Biochemistry of Phospholipids, Szuhaj B, van Nieuwenhuyzen W, eds. AOCS Press, Champaign, pp. 1429.

[36] Parson CG, Stoffler A, Danysz W (2007) Memantine: A NMDA receptor antagonist that improves memory by restoration of homeostasis in the glutamatergic system - too little activation is bad, too much is even worse. Neuropharmacol 53, 699-723.

[37] Putcha D, Brickhouse M, O'Keefe K, Sullivan C, Rentz D, Marshall G, Dickerson B, Sperling R (2011) Hippocampal hyperactivation associated with cortical thinning in Alzheimer's disease signature regions in non-demented elderly adults. $J$ Neurosci $\mathbf{3 1}, 17680-17688$.

[38] Sperling RA, Dickerson BC, Pihlajamaki M, Vannini P, LaViolette PS, Vitolo OV, Hedden T, Becker JA, Rentz DM, Selkoe DJ, Johnson KA (2010) Functional alterations in memory networks in early Alzheimer's disease. Neuromolecular Med 12, 27-43.

[39] Fayed N, Modrego PJ, Rojas-Salinas G, Aguilar K (2011) Brain glutamate levels are decreased in Alzheimer's disease: A magnetic resonance spectroscopy study. Am J Alzheimers Dis Other Demen 26, 450-456.

[40] Hoe HS, Fu Z, Makarova A, Lee JY, Lu C, Feng L, Pajoohesh-Ganji A, Matsuoka Y, Hyman BT, Ehlers MD, Vicini S, Pak DT, Rebeck GW (2009) The effects of amyloid precursor protein on postsynaptic composition and activity. J Biol Chem 284, 8495-8506.

[41] Lei P, Ayton S, Finkelstein DI, Spoerri L, Ciccotosto GD, Wright DK, Wong BX, Adlard PA, Cherny RA, Lam LQ, Roberts BR, Volitakis I, Egan GF, McLean CA, Cappai R, Duce JA, Bush AI (2012) Tau deficiency induces parkinsonism with dementia by impairing APP-mediated iron export. Nat Med 18, 291-295.

[42] Sandbrink R, Masters CL, Beyreuther K (1996) APP gene family. Alternative splicing generates functionally related isoforms. Ann NY Acad Sci 777, 281-287.

[43] LaFerla FM, Green KN, Oddo S (2007) Intracellular amyloid-beta in Alzheimer's disease. Nat Rev Neurosci 8, 499-509.

[44] Haass C, Selkoe DJ (2007) Soluble protein oligomers in neurodegeneration: Lessons from the Alzheimer's amyloid beta-peptide. Nat Rev Mol Cell Biol 8, 101-112.

[45] McLean CA, Cherny RA, Fraser FW, Fuller SJ, Smith MJ, Beyreuther K, Bush AI, Masters CL (1999) Soluble pool of Abeta amyloid as a determinant of severity of neurodegeneration in Alzheimer's disease. Ann Neurol 46, 860-866.

[46] Lacor PN, Buniel MC, Chang L, Fernandez SJ, Gong Y, Viola KL, Lambert MP, Velasco PT, Bigio EH, Finch CE, Krafft GA, Klein WL (2004) Synaptic targeting by Alzheimer's-related amyloid beta oligomers. J Neurosci 24, 10191-10200.

[47] De Felice FG, Wu D, Lambert MP, Fernandez SJ, Velasco PT, Lacor PN, Bigio EH, Jerecic J, Acton PJ, Shughrue PJ, Chen-Dodson E, Kinney GG, Klein WL (2008) Alzheimer's disease-type neuronal tau hyperphosphorylation induced by A beta oligomers. Neurobiol Aging 29, 1334-1347.

[48] Walsh DM, Klyubin I, Fadeeva JV, Cullen WK, Anwyl R, Wolfe MS, Rowan MJ, Selkoe DJ (2002) Naturally secreted oligomers of amyloid beta protein potently inhibit hippocampal long-term potentiation in vivo. Nature 416, 535-539.

[49] Roselli F, Tirard M, Lu J, Hutzier P, Lamberti P, Livrea P, Morabito MK, Almeida OF (2005) Soluble betaamyloid1-40 induces NMDA-dependent degradation of postsynaptic density-95 at glutamatergic synapses. $\mathrm{J} \mathrm{Neu-}$ rosci $\mathbf{2 5}, 11061-11070$.

[50] Ke YD, Suchowerska AK, van der Hoven J, De Silva DM, Wu CW, van Eersel J, Ittner A, Ittner LM (2012) Lessons from tau-deficient mice. Int J Alzheimers Dis 2012, 1-8.

[51] Alonso AC, Grundke-Iqbal I, Iqbal K (1996) Alzheimer's disease hyperphosphorylated tau sequesters normal tau into tangles of filaments and disassembles microtubules. Nat Med 2, 783-787.

[52] Stokin GB, Goldstein SB (2006) Axonal transport and Alzheimer's disease. Ann Rev Biochem 75, 607-627.

[53] Ittner LM, Gotz J (2011) Amyloid-beta and tau - a toxic pas de deux in Alzheimer's disease. Nat Rev Neurosci 12, 67-72.

[54] Rapoport M, Dawson HN, Binder LI, Vitek MP, Ferreira A (2002) Tau is essential to beta-amyloid-induced neurotoxicity. Proc Natl Acad Sci U S A 99, 6364-6369.

[55] Roberson ED, Scearce-Levie K, Palop JJ, Yan F, Cheng IH, Wu T, Gerstein H, Yu GQ, Mucke L (2007) Reducing endogenous tau ameliorates amyloid beta-induced deficits in an Alzheimer's disease mouse model. Science 316, 750-754.

[56] Ittner LM, Ke YD, Delerue F, Bi M, Gladbach A, van Eersel J, Wölfing H, Chieng BC, Christie MJ, Napier IA, Eckert A, Staufenbiel M, Hardeman E, Götz J (2010) Dendritic function of tau mediates amyloid-beta toxicity in Alzheimer's disease mouse models. Cell 142, 387-397.

[57] Nussbaum JM, Schilling S, Cynis H, Silva A, Swanson E, Wangsanut T, Tayler K, Wiltgen B, Hatami A, Rönicke R, Reymann K, Hutter-Paier B, Alexandru A, Jagla W, Graubner S, Glabe CG, Demuth HU, Bloom GS (2012) Prion-like behaviour and tau-dependent cytotoxicity of pyroglutamylated amyloid- $\beta$. Nature 485, 651-655.

[58] Huang Y (2006) Apolipoprotein E and Alzheimer disease. Neurology 66, S79-S85.

[59] Mahley RW, Weisgraber KH, Huang Y (2006) Apolipoprotein E4: A causative factor and therapeutic target in neuropathology, including Alzheimer's disease. Proc Natl Acad Sci U S A 103, 5644-5651.

[60] Bullido MJ, Artiga MJ, Recuero M, Sastre I, García MA, Aldudo J, Lendon C, Han SW, Morris JC, Frank A, Vázquez J, Goate A, Valdivieso F (1998) A polymorphism in the regulatory region of APOE associated with risk for Alzheimer's dementia. Nat Genet 18, 69-71.

[61] Laws SM, Hone E, Gandy S, Martins RN (2003) Expanding the association between the APOE gene and the risk of Alzheimer's disease: Possible roles for APOE promoter polymorphisms and alterations in APOE transcription. $J$ Neurochem 84, 1215-1236.

[62] Bales KR, Verina T, Cummins DJ, Du Y, Dodel RC, Saura J, Fishman CE, DeLong CA, Piccardo P, Petegnief V, Ghetti B, Paul SM (1999) Apolipoprotein E is essential for amyloid deposition in the APP(V717F) transgenic mouse model of Alzheimer's disease. Proc Natl Acad Sci U S A 96, 1523315238.

[63] Holtzman DM, Bales KR, Tenkova T, Fagan AM, Parsadanian M, Sartorius LJ, Mackey B, Olney J, McKeel D, 
Wozniak D, Paul SM (2000) Apolipoprotein E isoformdependent amyloid deposition and neuritic degeneration in a mouse model of Alzheimer's disease. Proc Natl Acad Sci U S A 97, 2892-2897.

[64] Cho HS, Hyman BT, Greenberg SM, Rebeck GW (2001) Quantitation of apoE domains in Alzheimer disease brain suggests a role for apoE in Abeta aggregation. J Neuropathol Exp Neurol 60, 342-349.

[65] Gibson GE, Haroutunian V, Zhang H, Park LC, Shi Q, Lesser M, Mohs RC, Sheu RK, Blass JP (2000) Mitochondrial damage in Alzheimer's disease varies with apolipoprotein E genotype. Ann Neurol 48, 297-303.

[66] Chang S, ran Ma T, Miranda RD, Balestra ME, Mahley RW, Huang Y (2005) Lipid- and receptor-binding regions of apolipoprotein E4 fragments act in concert to cause mitochondrial dysfunction and neurotoxicity. Proc Natl Acad Sci U S A 102, 18694-18699.

[67] Chen HK, Ji ZS, Dodson SE, Miranda RD, Rosenblum CI, Reynolds IJ, Freedman SB, Weisgraber KH, Huang Y, Mahley RW (2011) Apolipoprotein E4 domain interaction mediates detrimental effects on mitochondria and is a potential therapeutic target for Alzheimer disease. J Biol Chem 286, 5215-5221.

[68] Lee YJ, Choi IS, Park MH, Lee YM, Song JK, Kim YH, Kim KH, Hwang DY, Jeong JH, Yun YP, Oh KW, Jung JK, Han SB, Hong JT (2011) 4-O-Methylhonokiol attenuates memory impairment in presenilin 2 mutant mice through reduction of oxidative damage and inactivation of astrocytes and the ERK pathway. Free Radic Biol Med 50, 66-77.

[69] Hardy J (1997) Amyloid, the presenilins and Alzheimer's disease. Trends Neurosci 20, 154-159.

[70] Amtul Z, Lewis PA, Piper S, Crook R, Baker M, Findlay K, Singleton A, Hogg M, Younkin L, Younkin SG, Hardy J, Hutton M, Boeve BF, Tang-Wai D, Golde TE (2002) A presenilin 1 mutation associated with familial frontotemporal dementia inhibits gamma-secretase cleavage of APP and notch. Neurobiol Dis 9, 269-273.

[71] Lesné S, Ali C, Gabriel C, Croci N, MacKenzie ET, Glabe CG, Plotkine M, Marchand-Verrecchia C, Vivien D, Buisson A (2005) NMDA receptor activation inhibits alpha-secretase and promotes neuronal amyloid-beta production. J Neurosci 25, 9367-9377.

[72] Brorson JR, Bindokas VP, Iwama T, Marcuccilli CJ, Chisholm JC, Miller RJ (1995) The $\mathrm{Ca}^{2+}$ influx induced by beta-amyloid peptide 25-35 in cultured hippocampal neurons results from network excitation. J Neurobiol $\mathbf{2 6}$, 325-338.

[73] Fu W, Ruangkittisakul A, MacTavish D, Shi JY, Ballanyi $\mathrm{K}$, Jhamandas JH (2012) Amyloid $\beta$ (A $\beta$ ) peptide directly activates amylin-3 receptor subtype by triggering multiple intracellular signaling pathways. J Biol Chem 287, 1882018830.

[74] Bobich JA, Zheng Q, Campbell A (2004) Incubation of nerve endings with a physiological concentration of Abeta1-42 activates $\mathrm{CaV} 2.2(\mathrm{~N}$-Type)-voltage operated calcium channels and acutely increases glutamate and noradrenaline release. J Alzheimers Dis 6, 243-255.

[75] Bezprozvanny I, Mattson MP (2008) Neuronal calcium mishandling and the pathogenesis of Alzheimer's disease. Trends Neurosci 31, 454-463.

[76] Camandola S, Mattson MP (2011) Aberrant subcellular neuronal calcium regulation in aging and Alzheimer's disease. Biochim Biophys Acta 1813, 965-973.

[77] He Y, Cui J, Lee JC, Ding S, Chalimoniuk M, Simonyi A, Sun AY, Gu Z, Weisman GA, Wood WG, Sun GY
(2011) Prolonged exposure of cortical neurons to oligomeric amyloid- $\beta$ impairs NMDA receptor function via NADPH oxidase-mediated ROS production: Protective effect of green tea (-)-epigallocatechin-3-gallate. ASN Neuro 3, e00050.

[78] Wu J, Anwyl R, Rowan MJ (1995) beta-Amyloid selectively augments NMDA receptor-mediated synaptic transmission in rat hippocampus. Neuroreport 6, 2409-2413.

[79] Ferreira IL, Resende R, Ferreiro E, Rego AC, Pereira CF (2010) Multiple defects in energy metabolism in Alzheimer's disease. Curr Drug Targets 11, 11931206.

[80] Tominaga-Yoshino K, Uetsuki T, Yoshikawa K, Ogura A (2001) Neurotoxic and neuroprotective effects of glutamate are enhanced by introduction of amyloid precursor protein cDNA. Brain Res 918, 121-130.

[81] Costa RO, Lacor PN, Ferreira IL, Resende R, Auberson YP, Klein WL, Oliveira CR, Rego AC, Pereira CM (2012) Endoplasmic reticulum stress occurs downstream of GluN2B subunit of N-methyl-d-aspartate receptor in mature hippocampal cultures treated with amyloid- $\beta$ oligomers. Aging Cell 11, 823-833.

[82] Wu S, Basile AS, Barger SW (2007) Induction of serine racemase expression and $\mathrm{D}$-serine release from microglia by secreted amyloid precursor protein (sAPP). Curr Alzheimer Res 4, 243-251.

[83] Fernandez-Tome P, Brera B, Arevalo MA, de Ceballos ML (2004) Beta-amyloid25-35 inhibits glutamate uptake in cultured neurons and astrocytes: Modulation of uptake as a survival mechanism. Neurobiol Dis 15, 580-589.

[84] Matos M, Augusto E, Oliveira CR, Agostinho P (2008) Amyloid-beta peptide decreases glutamate uptake in cultured astrocytes: Involvement of oxidative stress and mitogen-activated protein kinase cascades. Neuroscience 156, 898-910.

[85] Liang Z, Liu F, Iqbal K, Grundke-Iqbal I, Gong CX (2009) Dysregulation of tau phosphorylation in mouse brain during excitotoxic damage. J Alzheimers Dis 17, 531-539.

[86] Suzuki T, Okumura-Noji K (1995) NMDA receptor subunits epsilon 1 (NR2A) and epsilon 2 (NR2B) are substrates for Fyn in the postsynaptic density fraction isolated from the rat brain. Biochem Biophys Res Commun 216, 582588.

[87] Götz J, Ittner A, Ittner LM (2012) Tau-targeted treatment strategies in Alzheimer's disease. Br J Pharmacol 165, 1246-1259.

[88] Boimel M, Grigoriadis N, Lourbopoulos A, Haber E, Abramsky O, Rosenmann H (2010) Efficacy and safety of immunization with phosphorylated tau against neurofibrillary tangles in mice. Exp Neurol 224, 472-485.

[89] Wisniewski T, Sigurdsson EM (2010) Murine models of Alzheimer's disease and their use in developing immunotherapies. Biochim Biophys Acta 1802, 847-859.

[90] Aono M, Lee Y, Grant ER, Zivin RA, Pearlstein RD, Warner DS, Bennett ER, Laskowitz DT (2002) Apolipoprotein E protects against NMDA excitotoxicity. Neurobiol Dis 11, 214-220.

[91] Lee Y, Aono M, Laskowitz D, Warner DS, Pearlstein RD (2004) Apolipoprotein E protects against oxidative stress in mixed neuronal-glial cell cultures by reducing glutamate toxicity. Neurochem Int 44, 107-118.

[92] Ong WY, He Y, Suresh S, Patel SC (1997) Differential expression of apolipoprotein $\mathrm{D}$ and apolipoprotein $\mathrm{E}$ in the kainic acid-lesioned rat hippocampus. Neuroscience 79, 359-367. 
[93] Buttini M, Masliah E, Yu GQ, Palop JJ, Chang S, Bernardo A, Lin C, Wyss-Coray T, Huang Y, Mucke L (2010) Cellular source of apolipoprotein E4 determines neuronal susceptibility to excitotoxic injury in transgenic mice. Am J Pathol 177, 563-569.

[94] Small GW, Ercoli LM, Silverman DH, Huang SC, Komo S, Bookheimer SY, Lavretsky H, Miller K, Siddarth P, Rasgon NL, Mazziotta JC, Saxena S, Wu HM, Mega MS, Cummings JL, Saunders AM, Pericak-Vance MA, Roses AD, Barrio JR, Phelps ME (2000) Cerebral metabolic and cognitive decline in persons at genetic risk for Alzheimer's disease. Proc Natl Acad Sci U S A 97, 6037-6042.

[95] Grilli M, Diodato E, Lozza G, Brusa R, Casarini M, Uberti D, Rozmahel R, Westaway D, St George-Hyslop P, Memo M, Ongini E (2000) Presenilin-1 regulates the neuronal threshold to excitotoxicity both physiologically and pathologically. Proc Natl Acad Sci U S A 97, 1282212827.

[96] Schulte EC, Slawik H, Schüle R, Gunther T, Hüll M (2009) Alterations in excitotoxicity and prostaglandin metabolism in a transgenic mouse model of Alzheimer's disease. $\mathrm{Neu}$ rochem Int 55, 689-696.

[97] Widner B, Leblhuber F, Walli J, Tilz GP, Demel U, Fuchs D (2000) Tryptophan degradation and immune activation in Alzheimer's disease. J Neural Transm 107, 343-353.

[98] Porter RJ, Lunn BS, O’Brien JT (2003) Effects of acute tryptophan depletion on cognitive function in Alzheimer's disease and in the healthy elderly. Psychol Med 33, 41-49.

[99] Rahman A, Ting K, Cullen KM, Braidy N, Brew BJ, Guillemin GJ (2009) The excitotoxin quinolinic acid induces tau phosphorylation in human neurons. PLoS One 4, e6344.

[100] Oda T, Pasinetti GM, Osterburg HH, Anderson C, Johnson SA, Finch CE (1994) Purification and characterization of brain clusterin. Biochem Biophys Res Commun 204, 11311136.

[101] Boggs LN, Fuson KS, Baez M, Churgay L, McClure D, Becker G, May PC (1996) Clusterin (Apo J) protects against in vitro amyloid-beta (1-40) neurotoxicity. J Neurochem $\mathbf{6 7}$, 1324-1327.

[102] Matsubara E, Soto C, Governale S, Frangione B, Ghiso J (1996) Apolipoprotein J and Alzheimer's amyloid beta solubility. Biochem J 316, 671-679.

[103] Ghiso J, Matsubara E, Koudinov A, Choi-Miura NH, Tomita M, Wisniewski T, Frangione B (1993) The cerebrospinalfluid soluble form of Alzheimer's amyloid beta is complexed to SP-40,40 (apolipoprotein J), an inhibitor of the complement membrane-attack complex. Biochem J 293, 27-30.

[104] Frippiat C, Chen QM, Zdanov S, Magalhaes JP, Remacle J, Toussaint $\mathrm{O}$ (2001) Subcytotoxic $\mathrm{H}_{2} \mathrm{O}_{2}$ stress triggers a release of transforming growth factor-beta 1 , which induces biomarkers of cellular senescence of human diploid fibroblasts. J Biol Chem 276, 2531-2537.

[105] Shin YJ, Kim JH, Seo JM, Lee SM, Hyon JY, Yu YS, Wee WR (2009) Protective effect of clusterin on oxidative stressinduced cell death of human corneal endothelial cells. Mol Vis 15, 2789-2795.

[106] Kim JH, Kim JH, Jun HO, Yu YS, Min BH, Park KH, Kim KW (2010) Protective effect of clusterin from oxidative stress-induced apoptosis in human retinal pigment epithelial cells. Invest Ophthalmol Vis Sci 51, 561-566.

[107] Zhang H, Kim JK, Edwards CA, Xu Z, Taichman R, Wang CY (2005) Clusterin inhibits apoptosis by interacting with activated Bax. Nat Cell Biol 7, 909-915.
[108] Trougakos IP, Lourda M, Antonelou MH, Kletsas D, Gorgoulis VG, Papassideri IS, Zou Y, Margaritis LH, Boothman DA, Gonos ES (2009) Intracellular clusterin inhibits mitochondrial apoptosis by suppressing p53-activating stress signals and stabilizing the cytosolic Ku70-Bax protein complex. Clin Cancer Res 15, 48-59.

[109] Xiao Q, Gil SC, Yan P, Wang Y, Han S, Gonzales E, Perez R, Cirrito JR, Lee JM (2012) Role of phosphatidylinositol clathrin assembly lymphoid-myeloid leukemia (PICALM) in intracellular amyloid precursor protein (APP) processing and amyloid plaque pathogenesis. J Biol Chem 287, 2127921289.

[110] Baig S, Joseph SA, Tayler H, Abraham R, Owen MJ, Williams J, Kehoe PG, Love S (2010) Distribution and expression of picalm in Alzheimer disease. J Neuropathol Exp Neurol 69, 1071-1077.

[111] Harel A, Wu F, Mattson MP, Morris CM, Yao PJ (2008) Evidence for CALM in directing VAMP2 trafficking. Traffic 9, 417-429.

[112] Klebig ML, Wall MD, Potter MD, Rowe EL, Carpenter DA, Rinchik EM (2003) Mutations in the clathrin-assembly gene Picalm are responsible for the hematopoietic and iron metabolism abnormalities in fit1 mice. Proc Natl Acad Sci U S A 100, 8360-8365.

[113] Treusch S, Hamamichi S, Goodman JL, Matlack KE, Chung CY, Baru V, Shulman JM, Parrado A, Bevis BJ, Valastyan JS, Han H, Lindhagen-Persson M, Reiman EM, Evans DA, Bennett DA, Olofsson A, DeJager PL, Tanzi RE, Caldwell KA, Caldwell GA, Lindquist S (2011) Functional links between A $\beta$ toxicity, endocytic trafficking, and Alzheimer's disease risk factors in yeast. Science 334, 1241-1245.

[114] D'Angelo F, Vignaud H, Di Martino J, Salin B, Devin A, Cullin C, Marchal C (2013) A yeast model for amyloid- $\beta$ aggregation exemplifies the role of membrane trafficking and PICALM in cytotoxicity. Dis Model Mech 6, 206-216.

[115] Rudinskiy N, Grishchuk Y, Vaslin A, Puyal J, Delacourte A, Hirling H, Clarke PG, Luthi-Carter R (2009) Calpain hydrolysis of alpha- and beta2-adaptins decreases clathrin-dependent endocytosis and may promote neurodegeneration. J Biol Chem 284, 12447-12458.

[116] McGreal E, Gasque P (2002) Structure-function studies of the receptors for complement C1q. Biochem Soc Trans 30, 1010-1014.

[117] Ten VS, Yao J, Ratner V, Sosunov S, Fraser DA, Botto M, Sivasankar B, Morgan BP, Silverstein S, Stark R, Polin R, Vannucci SJ, Pinsky D, Starkov AA (2010) Complement component $\mathrm{clq}$ mediates mitochondria-driven oxidative stress in neonatal hypoxic-ischemic brain injury. J Neurosci 30, 2077-2087.

[118] Gao LJ, Gu PQ, Fan WM, Liu Z, Qiu F, Peng YZ, Guo $\mathrm{XR}$ (2011) The role of $\mathrm{gClqR}$ in regulating survival of human papillomavirus 16 oncogene-transfected cervical cancer cells. Int J Oncol 39, 1265-1272.

[119] McGee AM, Baines CP (2011) Complement 1q-binding protein inhibits the mitochondrial permeability transition pore and protects against oxidative stress-induced death. Biochem J 433, 119-125.

[120] Chu Y, Jin X, Parada I, Pesic A, Stevens B, Barres B, Prince DA (2010) Enhanced synaptic connectivity and epilepsy in C1q knockout mice. Proc Natl Acad Sci U S A 107, 79757980.

[121] Di Paolo G, Sankaranarayanan S, Wenk MR, Daniell L, Perucco E, Caldarone BJ, Flavell R, Picciotto MR, Ryan TA, Cremona O, De Camilli P (2002) Decreased synaptic vesicle 
recycling efficiency and cognitive deficits in amphiphysin 1 knockout mice. Neuron 33, 789-804.

[122] Kim WS, Fitzgerald ML, Kang K, Okuhira K, Bell SA, Manning JJ, Koehn SL, Lu N, Moore KJ, Freeman MW (2005) Abca7 null mice retain normal macrophage phosphatidylcholine and cholesterol efflux activity despite alterations in adipose mass and serum cholesterol levels. J Biol Chem $\mathbf{2 8 0}$ 3989-3995.

[123] Jehle AW, Gardai SJ, Li S, Linsel-Nitschke P, Morimoto K, Janssen WJ, Vandivier RW, Wang N, Greenberg S, Dale BM, Qin C, Henson PM, Tall AR (2006) ATP-binding cassette transporter A7 enhances phagocytosis of apoptotic cells and associated ERK signaling in macrophages. J Cell Biol 174, 547-556.

[124] Liang Y, Buckley TR, Tu L, Langdon SD, Tedder TF (2001) Structural organization of the human MS4A gene cluster on Chromosome 11q12. Immunogenetics 53, 357-368.

[125] Koslowski M, Sahin U, Dhaene K, Huber C, Türeci O (2008) MS4A12 is a colon-selective store-operated calcium channel promoting malignant cell processes. Cancer Res $\mathbf{6 8}$ 3458-3466.

[126] Cormont M, Metón I, Mari M, Monzo P, Keslair F, Gaskin C, McGraw TE, Le Marchand-Brustel Y (2003) CD2AP/CMS regulates endosome morphology and traffic to the degradative pathway through its interaction with Rab4 and c-Cbl. Traffic 4, 97-112.

[127] Carter C (2011) Alzheimer's disease: APP, gamma secretase, APOE, CLU, CR1, PICALM, ABCA7, BIN1, CD2AP, CD33, EPHA1, and MS4A2, and their relationships with herpes simplex, C. pneumoniae, other suspect pathogens, and the immune system. Int $J$ Alzheimers Dis 2011, 501862.

[128] von Gunten S, Yousefi S, Seitz M, Jakob SM, Schaffner T, Seger R, Takala J, Villiger PM, Simon HU (2005) Siglec-9 transduces apoptotic and non-apoptotic death signals into neutrophils depending on the pro-inflammatory cytokine environment. Blood 106, 1423-1431.

[129] von Gunten S, Simon HU (2006) Sialic acid binding immunoglobulin-like lectins may regulate innate immune responses by modulating the life span of granulocytes. FASEB J 20, 601-605.

[130] Nutku E, Hudson SA, Bochner BS (2005) Mechanism of Siglec-8-induced human eosinophil apoptosis: Role of caspases and mitochondrial injury. Biochem Biophys Res Commun 336, 918-924.

[131] Cissé M, Halabisky B, Harris J, Devidze N, Dubal DB, Sun B, Orr A, Lotz G, Kim DH, Hamto P, Ho K, Yu GQ, Mucke L (2011) Reversing EphB2 depletion rescues cognitive functions in Alzheimer model. Nature 469, 47-52.

[132] Sloniowski S, Ethell IM (2012) Looking forward to EphB signaling in synapses. Semin Cell Dev Biol 23, 75-82.

[133] Barthet G, Dunys J, Shao Z, Xuan Z, Ren Y, Xu J, Arbez N, Mauger G, Bruban J, Georgakopoulos A, Shioi J, Robakis NK (2013) Presenilin mediates neuroprotective functions of ephrinB and brain-derived neurotrophic factor and regulates ligand-induced internalization and metabolism of EphB2 and TrkB receptors. Neurobiol Aging 34, 499-510.

[134] de la Monte SM, Wands JR (2008) Alzheimer's disease is type 3 diabetes-evidence reviewed. J Diabetes Sci Technol 2, 1101-1113.

[135] Talbot K, Wang HY, Kazi H, Han LY, Bakshi KP, Stucky A, Fuino RL, Kawaguchi KR, Samoyedny AJ, Wilson RS, Arvanitakis Z, Schneider JA, Wolf BA, Bennett DA, Trojanowski JQ, Arnold SE (2012) Demonstrated brain insulin resistance in Alzheimer's disease patients is associated with IGF-1 resistance, IRS-1 dysregulation, and cognitive decline. J Clin Invest 122, 1316-1338.

[136] Bomfim TR, Forny-Germano L, Sathler LB, Brito-Moreira J, Houzel JC, Decker H, Silverman MA, Kazi H, Melo HM, McClean PL, Holscher C, Arnold SE, Talbot K, Klein WL, Munoz DP, Munoz DP, De Felice FG (2012) An anti-diabetes agent protects the mouse brain from defective insulin signaling caused by Alzheimer's disease-associated A $\beta$ oligomers. J Clin Invest 122, 1339-1353.

[137] Ma QL, Yang F, Rosario ER, Ubeda OJ, Beech W, Gant DJ, Chen PP, Hudspeth B, Chen C, Zhao Y, Vinters HV, Frautschy SA, Cole GM (2009) Beta-amyloid oligomers induce phosphorylation of tau and inactivation of insulin receptor substrate via c-Jun N-terminal kinase signaling: Suppression by omega-3 fatty acids and curcumin. $\mathrm{J} \mathrm{Neu}$ rosci 29, 9078-9089.

[138] Farooqui AA, Farooqui T, Panza F, Frisardi V (2012) Metabolic syndrome as a risk factor for neurological disorders. Cell Mol Life Sci 69, 741-762.

[139] Camacho A, Montiel T, Massieu L (2007) Sustained metabolic inhibition induces an increase in the content and phosphorylation of the NR2B subunit of N-methyl-Daspartate receptors and a decrease in glutamate transport in the rat hippocampus in vivo. Neuroscience 145, 873-886.

[140] Bennett RG, Duckworth WC, Hamel FG (2000) Degradation of amylin by insulin-degrading enzyme. $J$ Biol Chem 275, 36621-36625.

[141] Kurochkin IV (2001) Insulin-degrading enzyme: Embarking on amyloid destruction. Trends Biochem Sci 26, 421-425.

[142] Cook DG, Leverenz JB, McMillan PJ, Kulstad JJ, Ericksen S, Roth RA, Schellenberg GD, Jin LW, Kovacina KS, Craft S (2003) Reduced hippocampal insulin-degrading enzyme in lateonset Alzheimer's disease is associated with the apolipoprotein Eepsilon4 allele. Am J Pathol 162, 313319.

[143] de la Monte SM (2012) Contributions of brain insulin resistance and deficiency in amyloid-related neurodegeneration in Alzheimer's disease. Drugs 72, 49-66.

[144] Ke YD, Delerue F, Gladbach A, Gotz J, Ittner LM (2009) Experimental diabetes mellitus exacerbates tau pathology in a transgenic mouse model of Alzheimer's disease. PLoS One 4, e7917.

[145] Farris W, Mansourian S, Chang Y, Lindsley L, Eckman EA, Frosch MP, Eckman CB, Tanzi RE, Selkoe DJ, Guenette S (2003) Insulin-degrading enzyme regulates the levels of insulin, amyloid beta-protein, and the beta-amyloid precursor protein intracellular domain in vivo. Proc Natl Acad Sci U S A 100, 4162-4167.

[146] Bosco D, Fava A, Plastino M, Montaecini T, Puja A (2011) Possible implications of insulin resistance and glucose metabolism in Alzheimer's disease pathogenesis. J Cell Mol Med 15, 1807-1821.

[147] Yamagishi S, Nakamura K, Inoue H, Kikuchi S, Takeuchi M (2005) Serum or cerebrospinal fluid levels of glyceraldehyde-derived advanced glycation end products (AGEs) may be a promising biomarker for early detection of Alzheimer's disease. Med Hypotheses 64, 1205-1207.

[148] Kilbride SM, Gluchowska SA, Telford JE, O'Sullivan C, Davey GP (2011) High-level inhibition of mitochondrial complexes III and IV is required to increase glutamate release from the nerve terminal. Mol Neurodegener 26, 53.

[149] Lustbader JW, Cirilli M, Lin C, Xu HW, Takuma K, Wang N, Caspersen C, Chen X, Pollak S, Chaney M, Trinchese F, Liu S, Gunn-Moore F, Lue LF, Walker DG, Kuppusamy 
P, Zewier ZL, Arancio O, Stern D, Yan SS, Wu H (2004) ABAD directly links Abeta to mitochondrial toxicity in Alzheimer's disease. Science 304, 448-452.

[150] Manczak M, Anekonda TS, Henson E, Park BS, Quinn J, Reddy PH (2006) Mitochondria are a direct site of A beta accumulation in Alzheimer's disease neurons: Implications for free radical generation and oxidative damage in disease progression. Hum Mol Genet 15, 1437-1449.

[151] Dumont M, Beal MF (2011) Neuroprotective strategies involving ROS in Alzheimer disease. Free Radic Biol Med 51, 1014-1026.

[152] Farooqui AA (2011) Lipid Mediators and their Metabolism in the Brain, Springer, New York.

[153] Lieb W, Beiser AS, Vasan RS, Tan ZS, Au R, Harris TB, Roubenoff R, Auerbach S, DeCarli C, Wolf PA, Seshadri S (2009) Association of plasma leptin levels with incident Alzheimer disease and MRI measures of brain aging. JAMA 302, 2565-2572.

[154] Tezapsidis N, Johnston JM, Smith MA, Ashford JW, Casadesus G, Robakis NK, Wolozin B, Perry G, Zhu X, Greco SJ, Sarkar S (2009) Leptin: A novel therapeutic strategy for Alzheimer's disease. J Alzheimers Dis 16, 731740 .

[155] Shanley LJ, Irving AJ, Harvey J (2001) Leptin enhances NMDA receptor function and modulates hippocampal synaptic plasticity. J Neurosci 21, RC186.

[156] Oomura Y, Hori N, Shiraishi T, Fukunaga K, Takeda H, Tsuji M, Matsumiya T, Ishibashi M, Aou S, Li XL (2006) Leptin facilitates learning and memory performance and enhances hippocampal CA1 longterm potentiation and CaMK II phosphorylation in rats. Peptides 27, 2738-2749.

[157] Fewlass DC, Noboa K, Pi-Sunyer FX, Johnston JM, Yan SD, Tezapsidis N (2004) Obesity-related leptin regulates Alzheimer's Abeta. FASEB J 18, 1870-1878.

[158] Greco SJ, Bryan KJ, Sarkar S, Zhu X, Smith MA, Ashford JW, Johnston JM, Tezapsidis N, Casadesus G (2010) Chronic leptin supplementation ameliorates pathology and improves cognitive performance in a transgenic mouse model of Alzheimer's disease. J Alzheimers Dis 19, 11551167.

[159] Beccano-Kelly D, Harvey J (2012) Leptin: A novel therapeutic target in Alzheimer's disease? Int J Alzheimers Dis 2012, 594137.

[160] Pichika R, Taha AY, Gao F, Kotta K, Cheon Y, Chang L, Kiesewetter D, Rapoport SI, Eckelman WC (2012) The synthesis and in vivo pharmacokinetics of fluorinated arachidonic acid: Implications for imaging neuroinflammation. $J$ Nucl Med 53, 1383-1391.

[161] Esposito G, Giovacchini G, Liow JS, Bhattacharjee AK, Greenstein D, Schapiro M, Hallett M, Herscovitch P, Eckelman WC, Carson RE, Rapoport SI (2008) Imaging neuroinflammation in Alzheimer's disease with radiolabeled arachidonic acid and PET. J Nucl Med 49, 1414-1421.

[162] Kanfer JN, Sorrentino G, Sitar DS (1998) Phospholipases as mediators of amyloid beta peptide neurotoxicity: An early event contributing to neurodegeneration characteristic of Alzheimer's disease. Neurosci Lett 257, 93-96.

[163] Sanchez-Mejia RO, Newman JW, Toh S, Yu GQ, Zhou Y, Halabisky B, Cissé M, Scearce-Levie K, Cheng IH, Gan L, Palop JJ, Bonventre JV, Mucke L (2008) Phospholipase $\mathrm{A}_{2}$ reduction ameliorates cognitive deficits in a mouse model of Alzheimer's disease. Nat Neurosci 11, 1311-1318.

[164] Ong WY, Sandhya TL, Horrocks LA, Farooqui AA (1999) Distribution of cytoplasmic phospholipase $\mathrm{A}_{2}$ in the normal rat brain. J Hirnforsch 39, 391-400.
[165] Ong WY, Lu XR, Ong BK, Horrocks LA, Farooqui AA, Lim SK (2003) Quinacrine abolishes increases in cytoplasmic phospholipase $\mathrm{A}_{2}$ mRNA levels in the rat hippocampus after kainate-induced neuronal injury. Exp Brain Res 148, 521524.

[166] Sandhya TL, Ong WY, Horrocks LA, Farooqui AA (1998) A light and electron microscopic study of cytoplasmic phospholipase $\mathrm{A}_{2}$ and cyclooxygenase- 2 in the hippocampus after kainate lesions. Brain Res 788, 223-231.

[167] Ong WY, Lu XR, Hu CY, Halliwell B (2000) Distribution of hydroxynonenal-modified proteins in the kainate-lesioned rat hippocampus: Evidence that hydroxynonenal formation precedes neuronal cell death. Free Radic Biol Med 28, 12141221.

[168] Lu XR, Ong WY, Halliwell B, Horrocks LA, Farooqui AA (2001) Differential effects of calcium-dependent and calcium-independent phospholipase $\mathrm{A}(2)$ inhibitors on kainate-induced neuronal injury in rat hippocampal slices. Free Radic Biol Med 30, 1263-1273.

[169] Moses GS, Jensen MD, Lue LF, Walker DG, Sun AY, Simonyi A, Sun GY (2006) Secretory PLA 2 -IIA: A new inflammatory factor for Alzheimer's disease. J Neuroinflammation, 3, 28.

[170] Jensen MD, Sheng W, Simonyi A, Johnson GS, Sun AY, Sun GY (2009) Involvement of oxidative pathways in cytokine-induced secretory phospholipase $\mathrm{A}_{2}$-IIA in astrocytes. Neurochem Int 55, 362-368.

[171] Thwin MM, Ong WY, Fong CW, Sato K, Kodama K, Farooqui AA, Gopalakrishnakone P (2003) Secretory phospholipase $A_{2}$ activity in the normal and kainate injected rat brain, and inhibition by a peptide derived from python serum. Exp Brain Res 150, 427-433.

[172] Than A, Tan Y, Ong WY, Farooqui AA, Chen P (2012) Kainate receptors mediate regulated exocytosis of secretory phospholipase A(2) in SH-SY5Y neuroblastoma cells. Neurosignals 20, 72-85.

[173] Wei S, Ong WY, Thwin MM, Fong CW, Farooqui AA, Gopalakrishnakone P, Hong W (2003) Group IIA secretory phospholipase $\mathrm{A}_{2}$ stimulates exocytosis and neurotransmitter release in pheochromocytoma-12 cells and cultured rat hippocampal neurons. Neuroscience 121, 891-898.

[174] Yang X, Sheng W, He Y, Cui J, Haidekker MA, Sun GY, Lee JC (2010) Secretory phospholipase $A_{2}$ type III enhances alpha-secretase-dependent amyloid precursor protein processing through alterations in membrane fluidity. J Lipid Res 51, 957-966.

[175] Zhu D, Lai Y, Shelat PB, Hu C, Sun GY, Lee JC (2006) Phospholipases $\mathrm{A}_{2}$ mediate amyloid-beta peptide-induced mitochondrial dysfunction. J Neurosci 26, 11111-11119.

[176] Lee JC, Simonyi A, Sun AY, Sun GY (2009) Phospholipases $A_{2}$ and neural membrane dynamics: Implications for Alzheimer's disease. J Neurochem 116, 813-819.

[177] Shelat PB, Chalimoniuk M, Wang JH, Strosznajder JB, Lee JC, Sun AY, Simonyi A, Sun GY (2008) Amyloid beta peptide and NMDA induce ROS from NADPH oxidase and AA release from cytosolic phospholipase $\mathrm{A}_{2}$ in cortical neurons. J Neurochem 106, 45-55.

[178] Zhu D, Hu C, Sheng W, Tan KS, Haidekker MA, Sun AY, Sun GY, Lee JC (2009) NAD(P)H oxidase-mediated reactive oxygen species production alters astrocyte membrane molecular order via phospholipase A2. Biochem J 421, 201210.

[179] Askarova S, Yang X, Sheng W, Sun GY, Lee JC (2011) Role of $\mathrm{A} \beta$-receptor for advanced glycation endproducts interaction in oxidative stress and cytosolic phospholipase 
$\mathrm{A}_{2}$ activation in astrocytes and cerebral endothelial cells. Neuroscience 199, 375-385.

[180] Esterbauer H, Schaur RJ, Zollner H (1991) Chemistry and biochemistry of 4-hydroxynonenal, malonaldehyde and related aldehydes. Free Radic Biol Med 11, 81-128.

[181] Mark RJ, Lovell MA, Markesbery WR, Uchida K, Mattson MP (1997) A role for 4-hydroxynonenal, an aldehydic product of lipid peroxidation, in disruption of ion homeostasis and neuronal death induced by amyloid beta-peptide. $J$ Neurochem 68, 255-264.

[182] Keller JN, Mark RJ, Bruce AJ, Blanc E, Rothstein JD, Uchida K, Waeg G, Mattson MP (1997) 4-Hydroxynonenal, an aldehydic product of membrane lipid peroxidation, impairs glutamate transport and mitochondrial function in synaptosomes. Neuroscience 80, 685-696.

[183] Choi SH, Aid S, Caracciolo L, Sakura Minami S, Niikura T, Matsuoka Y, Turner RS, Mattson MP, Bosetti F (2013) Cyclooxygenase-1 inhibition reduces amyloid pathology and improves memory deficits in a mouse model of Alzheimer's disease. J Neurochem 124, 59-68.

[184] Farooqui AA (2009) Hot Topics in Neural Membrane Lipidology, Springer, New York.

[185] Farooqui AA, Horrocks LA (2007) Glycerophospholipids in Brain: Phospholipase $A_{2}$ in Neurological Disorders, Springer, New York.

[186] Ma MT, Yeo JF, Farooqui AA, Zhang J, Chen P, Ong WY (2010) Differential effects of lysophospholipids on exocytosis in rat PC12 cells. J Neural Transm 117, 301308.

[187] Talbot K, Young RA, Jolly-Tornetta C, Lee VM, Trojanowski JQ, Wolf BA (2000) A frontal variant of Alzheimer's disease exhibits decreased calcium-independent phospholipase $\mathrm{A}_{2}$ activity in the prefrontal cortex. Neurochem Int 37, 17-31.

[188] Gattaz WF, Forlenza OV, Talib LL, Barbosa NR, Bottino CM (2004) Platelet phospholipase A(2) activity in Alzheimer's disease and mild cognitive impairment. J Neural Transm 111, 591-601

[189] Ong WY, Farooqui T, Farooqui AA (2010) Involvement of cytosolic phospholipase A(2), calcium independent phospholipase $\mathrm{A}(2)$ and plasmalogen selective phospholipase A(2) in neurodegenerative and neuropsychiatric conditions. Curr Med Chem 17, 2746-2763.

[190] Dyall SC, Michael GJ, Whelpton R, Scott AG, MichaelTitus AT (2007) Dietary enrichment with omega-3 polyunsaturated fatty acids reverses age-related decreases in the GluR2 and NR2B glutamate receptor subunits in rat forebrain. Neurobiol Aging 28, 424-439.

[191] Ménard C, Patenaude C, Gagné AM, Massicotte G (2009) AMPA receptor-mediated cell death is reduced by docosahexaenoic acid but not by eicosapentaenoic acid in area CA1 of hippocampal slice cultures. J Neurosci Res $\mathbf{8 7}, 876$ 886.

[192] Bazan NG, Musto AE, Knott EJ (2011) Endogenous signaling by omega-3 docosahexaenoic acid-derived mediators sustains homeostatic synaptic and circuitry integrity. Mol Neurobiol 44, 216-222.

[193] Allyson J, Bi X, Baudry M, Massicotte G (2012) Maintenance of synaptic stability requires calcium-independent phospholipase $\mathrm{A}_{2}$ activity. Neural Plast 2012, 569149.

[194] Kuo YM, Emmerling MR, Bisgaier CL, Essenburg AD, Lampert HC, Drumm D, Roher AE (1998) Elevated lowdensity lipoprotein in Alzheimer's disease correlates with brain abeta 1-42 levels. Biochem Biophys Res Commun 252 , 711-715.
[195] Lazar AN, Bich C, Panchal M, Desbenoit N, Petit VW, Touboul D, Dauphinot L, Marquer C, Laprévote O, Brunelle A, Duyckaerts C (2013) Time-of-flight secondary ion mass spectrometry (TOF-SIMS) imaging reveals cholesterol overload in the cerebral cortex of Alzheimer disease patients. Acta Neuropathol 125, 133-144.

[196] Prasanthi JR, Huls A, Thomasson S, Thompson A, Schommer E, Ghribi O (2009) Differential effects of 24-hydroxycholesterol and 27-hydroxycholesterol on betaamyloid precursor protein levels and processing in human neuroblastoma SH-SY5Y cells. Mol Neurodegener 4, 1.

[197] Barrett PJ, Song Y, Van Horn WD, Hustedt EJ, Schafer JM, Hadziselimovic A, Beel AJ, Sanders CR (2012) The amyloid precursor protein has a flexible transmembrane domain and binds cholesterol. Science 336, 1168-1171.

[198] Chen P, Shen A, Zhao W, Baek SJ, Yuan H, Hu J (2009) Raman signature from brain hippocampus could aid Alzheimer's disease diagnosis. Appl Opt 48, 47434748.

[199] Ong WY, Goh EW, Lu XR, Farooqui AA, Patel SC, Halliwell $B$ (2003) Increase in cholesterol and cholesterol oxidation products, and role of cholesterol oxidation products in kainate-induced neuronal injury. Brain Pathol 13, 250262.

[200] He X, Jenner AM, Ong WY, Farooqui AA, Patel SC (2006) Lovastatin modulates increased cholesterol and oxysterol levels and has a neuroprotective effect on rat hippocampal neurons after kainate injury. J Neuropathol Exp Neurol 65, 652-663.

[201] Kim JH, Jittiwat J, Ong WY, Farooqui AA, Jenner AM (2010) Changes in cholesterol biosynthetic and transport pathways after excitotoxicity. J Neurochem 112, 34-41.

[202] Ong WY, Kim JH, He X, Chen P, Farooqui AA, Jenner AM (2010) Changes in brain cholesterol metabolome after excitotoxicity. Mol Neurobiol 41, 299-313.

[203] Wolozin B (2004) Cholesterol and the biology of Alzheimer's disease. Neuron 41, 7-10.

[204] Fantini J, Yahi N (2010) Molecular insights into amyloid regulation by membrane cholesterol and sphingolipids: Common mechanisms in neurodegenerative diseases. Expert Rev Mol Med 12, e27.

[205] Zhang J, Xue R, Ong WY, Chen P (2009) Roles of cholesterol in vesicle fusion and motion. Biophys J 97, 13711380 .

[206] Nelson TJ, Alkon DL (2005) Oxidation of cholesterol by amyloid precursor protein and beta-amyloid peptide. $J$ Biol Chem 280, 7377-7387.

[207] Berthier A, Lemaire-Ewing S, Prunet C, Montange T, Vejux A, Pais de Barros JP, Monier S, Gambert P, Lizard G, Néel D (2005) 7-Ketocholesterol-induced apoptosis. Involvement of several pro-apoptotic but also anti-apoptotic calcium-dependent transduction pathways. FEBS $J$ 272, 3093-3104.

[208] Han JH, Kim YJ, Han ES, Lee CS (2007) Prevention of 7-ketocholesterol-induced mitochondrial damage and cell death by calmodulin inhibition. Brain Res 1137, 11-19.

[209] Luthra S, Dong J, Gramajo AL, Chwa M, Kim DW, Neekhra A, Kuppermann BD, Kenney MC (2008) 7Ketocholesterol activates caspases-3/7, -8 , and -12 in human microvascular endothelial cells in vitro. Microvasc Res $\mathbf{7 5}$, 343-350.

[210] Ma MT, Zhang J, Farooqui AA, Chen P, Ong WY (2010) Effects of cholesterol oxidation products on exocytosis. Neurosci Lett 476, 36-41. 
[211] Haughey NJ, Bandaru VV, Bae M, Mattson MP (2010) Roles for dysfunctional sphingolipid metabolism in Alzheimer's disease neuropathogenesis. Biochim Biophys Acta 1801, 878-886.

[212] Han X, Holtzman D, McKeel DW, Jr., Kelley J, Morris JC (2002) Substantial sulfatide deficiency and ceramide elevation in very early Alzheimer's disease: Potential role in disease pathogenesis. J Neurochem 82, 809-818.

[213] Cutler RG, Kelley J, Storie K, Pedersen WA, Tammara A, Hatanpaa K, Troncoso JC, Mattson MP (2004) Involvement of oxidative stress-induced abnormalities in ceramide and cholesterol metabolism in brain aging and Alzheimer's disease. Proc Natl Acad Sci U S A 101, 2070-2075.

[214] He X, Huang Y, Li B, Gong CX, Schuchman EH (2010) Deregulation of sphingolipid metabolism in Alzheimer's disease. Neurobiol Aging 31, 398-408.

[215] Tong M, de la Monte SM (2009) Mechanisms of ceramide-mediated neurodegeneration. J Alzheimer Dis 16, 705-714.

[216] Guan XL, He X, Ong WY, Yeo WK, Shui G, Wenk MR (2006) Non-targeted profiling of lipids during kainateinduced neuronal injury. FASEB $J$ 20, 1152-1161.

[217] He X, Guan XL, Ong WY, Farooqui AA, Wenk MR (2007) Expression, activity, and role of serine palmitoyltransferase in the rat hippocampus after kainate injury. J Neurosci Res 85, 423-432.

[218] Tang N, Ong WY, Zhang EM, Chen P, Yeo JF (2007) Differential effects of ceramide species on exocytosis in rat PC12 cells. Exp Brain Res 183, 241-247.

[219] Barry G, Ross IL (2008) Neurosteroids and sporadic Alzheimer's disease. Curr Alzheimer Res 5, 367-374.

[220] Chia WJ, Jenner AM, Farooqui AA, Ong WY (2008) Changes in cytochrome P450 side chain cleavage expression in the rat hippocampus after kainate injury. Exp Brain Res 186, 143-149.

[221] Mizuno $T$ (2012) The biphasic role of microglia in Alzheimer's disease. Int J Alzheimers Dis 2012, 737846.

[222] Rogove AD, Tsirka SE (1998) Neurotoxic responses by microglia elicited by excitotoxic injury in the mouse hippocampus. Curr Biol 8, 19-25.

[223] Meda L, Cassatella MA, Szendrei GI, Otvos L Jr., Baron P, Villalba M, Ferrari D, Rossi F (1995) Activation of microglial cells by beta-amyloid protein and interferongamma. Nature 374, 647-650.

[224] Halliwell B, Gutteridge JM (1997) Lipid peroxidation in brain homogenates: The role of iron and hydroxyl radicals. J Neurochem 69, 1330-1331.

[225] Chao C, Hu S, Molitor T, Shaskan E, Peterson P (1992) Activated microglia mediate neuronal cell injury via a nitric oxide mechanism. J Immunol 149, 2736-2741.

[226] Martínez-Ruiz A, Cadenas S, Lamas S (2011) Nitric oxide signaling: Classical, less classical and nonclassical mechanisms. Free Radic Biol Med 51, 17-29.

[227] Abrams AJ, Farooq A, Wang G (2011) S-nitrosylation of ApoE in Alzheimer's disease. Biochemistry 50, 34053407.

[228] Qin S, Colin C, Hinners I, Gervais A, Cheret C, Mallat M (2006) System Xc- and apolipoprotein E expressed by microglia have opposite effects on the neurotoxicity of amyloid-beta peptide 1-40. J Neurosci 26, 3345-3356.

[229] Murugan M, Sivakumar V, Lu J, Ling EA, Kaur C (2011) Expression of N-methyl D-aspartate receptor subunits in amoeboid microglia mediates production of nitric oxide via $\mathrm{NF}-\kappa \mathrm{B}$ signaling pathway and oligodendrocyte cell death in hypoxic postnatal rats. Glia 59, 521-539.
[230] Kaindl AM, Degos V, Peineau S, Gouadon E, Chhor V, Loron G, Le Charpentier T, Josserand J, Ali C, Vivien D, Collingridge GL, Lombet A, Issa L, Rene F, Loeffler JP, Kavelaars A, Verney C, Mantz J, Gressens P (2012) Activation of microglial $\mathrm{N}$-methyl-D-aspartate receptors triggers inflammation and neuronal cell death in the developing and mature brain. Ann Neurol 72, 536-549.

[231] Steele ML, Robinson SR (2012) Reactive astrocytes give neurons less support: Implications for Alzheimer's disease. Neurobiol Aging 33, 423e1-42313.

[232] Frederickson RC (1992) Astroglia in Alzheimer's disease. Neurobiol Aging 13, 239-253.

[233] Matos M, Augusto E, Machado NJ, dos Santos-Rodrigues A, Cunha RA, Agostinho P (2012) Astrocytic adenosine A2A receptors control the amyloid- $\beta$ peptide-induced decrease of glutamate uptake. J Alzheimers Dis 31, 555-567.

[234] Zhong N, Scearce-Levie K, Ramaswamy G, Weisgraber KH (2008) Apolipoprotein E4 domain interaction: Synaptic and cognitive deficits in mice. Alzheimers Dement 4 , 179-192.

[235] Smith MA, Harris PLR, Sayre LM, Perry G (1997) Iron accumulation in Alzheimer disease is a source of redoxgenerated free radicals. Proc Nat Acad Sci U S A 94, 98669868.

[236] Piñero DJ, Hu J, Connor JR (2000) Alterations in the interaction between iron regulatory proteins and their iron responsive element in normal and Alzheimer's diseased brains. Cell Mol Biol 46, 761-776.

[237] Silvestri L, Camaschella C (2008) A potential pathogenetic role of iron in Alzheimer's disease. J Cell Mol Med 12, 1548-1550.

[238] Egana JT, Zambrano C, Nunez MT, Gonzalez-Billault C, Maccioni RB (2003) Iron-induced oxidative stress modify tau phosphorylation patterns in hippocampal cell cultures. Biometals 16, 215-223.

[239] Jomova K, Valko M (2011) Importance of iron chelation in free radical-induced oxidative stress and human disease. Curr Pharm Design 17, 3460-3473.

[240] Butterfield DA, Bush AI (2004) Alzheimer's amyloid betapeptide (1-42): Involvement of methionine residue 35 in the oxidative stress and neurotoxicity properties of this peptide. Neurobiol Aging 25, 563-568.

[241] Ong WY, Ren MQ, Makjanic J, Lim TM, Watt F (1999) A nuclear microscopic study of elemental changes in the rat hippocampus after kainate-induced neuronal injury. $\mathrm{J} \mathrm{Neu}$ rochem 72, 1574-1579.

[242] Wang XS, Ong WY, Connor JR (2002) Increase in ferric and ferrous iron in the rat hippocampus with time after kainateinduced excitotoxic injury. Exp Brain Res 143, 137-148.

[243] Huang E, Ong WY (2005) Distribution of ferritin in the rat hippocampus after kainate-induced neuronal injury. Exp Brain Res 161, 502-511.

[244] Wang XS, Ong WY, Connor JR (2002) A light and electron microscopic study of divalent metal transporter-1 distribution in the rat hippocampus, after kainate-induced neuronal injury. Exp Neurol 177, 193-201.

[245] Huang E, Ong WY, Go ML, Connor JR (2006) Upregulation of iron regulatory proteins and divalent metal transporter1 isoforms in the rat hippocampus after kainate induced neuronal injury. Exp Brain Res 170, 376-386.

[246] Chen JH, Shahnavas S, Singh N, Ong WY, Walczyk T (2013) Stable iron isotope tracing reveals significant brain iron uptake in adult rats. Metallomics 5, 167-173.

[247] Ong WY, Tan B, Pan N, Jenner A, Whiteman M, Ong CN, Watt F, Halliwell B (2004) Increased iron staining in the 
cerebral cortex of cholesterol fed rabbits. Mech Ageing Dev $\mathbf{1 2 5}, 305-313$

[248] Ong WY, Jenner AM, Pan N, Ong CN, Halliwell B (2009) Elevated oxidative stress, iron accumulation around microvessels and increased 4-hydroxynonenal immunostaining in zone 1 of the liver acinus in hypercholesterolemic rabbits. Free Radic Res 43, 241-249.

[249] Ong WY, Halliwell B (2004) Iron, atherosclerosis, and neurodegeneration: A key role for cholesterol in promoting iron-dependent oxidative damage? Ann N Y Acad Sci 1012, 51-64.

[250] Ong WY, Ong BKC, Farooqui AA, Chiueh CC, Connor JR (2003) Iron and epilepsy. In Metal Ions and Neurodegenerative Disorders. Zatta P, ed. World Scientific, Singapore. pp. 365-398.

[251] Lipton SA (2007) Pathologically activated therapeutics for neuroprotection. Nat Rev Neurosci 8, 803-808.

[252] Burke D (2012) Donepezil or memantine improved cognitive functioning in moderate-to-severe Alzheimer disease. Ann Intern Med 156, JC6-J10.

[253] Annweiler C, Beauchet O (2012) Possibility of a new anti-Alzheimer's disease pharmaceutical composition combining memantine and vitamin D. Drugs Aging 29, 81-91.

[254] Seki M, Lipton SA (2008) Targeting excitotoxic/free radical signaling pathways for therapeutic intervention in glaucoma. Prog Brain Res 173, 495-510.

[255] Song MS, Rauw G, Baker GB, Kar S (2008) Memantine protects rat cortical cultured neurons against beta-amyloidinduced toxicity by attenuating tau phosphorylation. Eur $J$ Neurosci 28, 1989-2002.

[256] Chen CM, Lin JK, Liu SH, Lin-Shiau SY (2008) Novel regimen through combination of memantine and tea polyphenol for neuroprotection against brain excitotoxicity. J Neurosci Res 86, 2696-2704.

[257] Schmitt FA, van Dyck CH, Wichems CH, Olin JT, the Memantine MEM-MD-02 Study Group (2006) Cognitive response to memantine in moderate to severe Alzheimer disease patients already receiving donepezil: An exploratory reanalysis. Alzheimer Dis Assoc Disord 20, 255-262.

[258] Schmitt F, Ryan M, Cooper G (2007) A brief review of the pharmacologic and therapeutic aspects of memantine in Alzheimer's disease. Expert Opin Drug Metab Toxicol 3 , 135-141.

[259] Rogawski MA, Wenk GL (2003) The neuropharmacological basis for the use of memantine in the treatment of Alzheimer's disease. CNS Drug Rev 9, 275-308.

[260] Reisberg B, Doody R, Stöffler A, Schmitt F, Ferris S, Möbius HJ, Memantine Study, Group (2003) Memantine in moderate-to-severe Alzheimer's disease. $N$ Engl J Med 348, 1333-1341.

[261] Lipton SA (2006) Paradigm shift in neuroprotection by NMDA receptor blockade: Memantine and beyond. Nat Rev Drug Discov 5, 160-170.

[262] Nakamura T, Lipton SA (2007) S-Nitrosylation and uncompetitive/fast off-rate (UFO) drug therapy in neurodegenerative disorders of protein misfolding. Cell Death Differ 14, 1305-1314.

[263] Correia S, Carvalho C, Santos MS, Seiça R, Oliveira CR, Moreira PI (2008) Mechanisms of action of metformin in type 2 diabetes and associated complications: An overview. Mini Rev Med Chem 8, 1343-1354.

[264] Imfeld P, Bodmer M, Jick SS, Meier CR (2012) Metformin, other antidiabetic drugs, and risk of Alzheimer's disease: A population-based case-control study. J Am Geriatr Soc 60, 916-921.
[265] Chen Y, Zhou K, Wang R, Liu Y, Kwak YD, Ma T, Thompson RC, Zhao Y, Smith L, Gasparini L, Luo Z, Xu H, Liao FF (2009) Antidiabetic drug metformin (GlucophageR) increases biogenesis of Alzheimer's amyloid peptides via up-regulating BACE1 transcription. Proc Natl Acad Sci U S A 106, 3907-3912.

[266] Li Y, Duffy KB, Ottinger MA, Ray B, Bailey JA, Holloway HW, Tweedie D, Perry T, Mattson MP, Kapogiannis D, Sambamurti K, Lahiri DK, Greig NH (2010) GLP-1 receptor stimulation reduces amyloid-beta peptide accumulation and cytotoxicity in cellular and animal models of Alzheimer's disease. J Alzheimers Dis 19, 1205-1219.

[267] Ramirez C, Tercero I, Pineda A, Burgos JS (2011) Simvastatin is the statin that most efficiently protects against kainate-induced excitotoxicity and memory impairment. $J$ Alzheimers Dis 24, 161-174.

[268] Dolga AM, Nijholt IM, Ostroveanu A, Ten Bosch Q, Luiten PG, Eisel UL (2008) Lovastatin induces neuroprotection through tumor necrosis factor receptor 2 signaling pathways. J Alzheimers Dis 13, 111-122.

[269] Tong XK, Lecrux C, Rosa-Neto P, Hamel E (2012) Agedependent rescue by simvastatin of Alzheimer's disease cerebrovascular and memory deficits. J Neurosci 32, 47054715.

[270] Kimura M, Komatsu H, Ogura H, Sawada K (2005) Comparison of donepezil and memantine for protective effect against amyloid-beta(1-42) toxicity in rat septal neurons. Neurosci Lett 391, 17-21.

[271] Akasofu S, Kimura M, Kosasa T, Sawada K, Ogura H (2008) Study of neuroprotection of donepezil, a therapy for Alzheimer's disease. Chem Biol Interact 175, 222-226.

[272] Shen H, Kihara T, Hongo H, Wu X, Kem WR, Shimohama S, Akaike A, Niidome T, Sugimoto H (2010) Neuroprotection by donepezil against glutamate excitotoxicity involves stimulation of alpha7 nicotinic receptors and internalization of NMDA receptors. Br J Pharmacol 161, 127-139.

[273] Fu H, Li W, Liu Y, Lao Y, Liu W, Chen C, Yu H, Lee NT, Chang DC, Li P, Pang Y, Tsim KW, Li M, Han Y (2007) Mitochondrial proteomic analysis and characterization of the intracellular mechanisms of bis(7)-tacrine in protecting against glutamate-induced excitotoxicity in primary cultured neurons. J Proteome Res $\mathbf{6}$, 2435-2446.

[274] Chandra V, Pandav R, Dodge HH, Johnston JM, Belle SH, DeKosky ST, Ganguli M (2001) Incidence of Alzheimer's disease in a rural community in India: The Indo-US study. Neurology 57, 985-989.

[275] Yang F, Lim GP, Begum AN, Ubeda OJ, Simmons MR, Ambegaokar SS, Chen PP, Kayed R, Glabe CG, Frautschy SA, Cole GM (2005) Curcumin inhibits formation of amyloid beta oligomers and fibrils, binds plaques, and reduces amyloid in vivo. J Biol Chem 280, 5892-5901.

[276] Kawamoto EM, Scavone C, Mattson MP, Camandola S (2012) Curcumin requires tumor necrosis factor $\alpha$ signaling to alleviate cognitive impairment elicited by lipopolysaccharide. Neurosignals 21, 75-88.

[277] Butterfield DA, Perluigi M, Sultana R (2006) Oxidative stress in Alzheimer's disease brain: New insights from redox proteomics. Eur J Pharmacol 545, 39-50.

[278] Nunomura A, Castellani RJ, Zhu X, Moreira PI, Perry G, Smith MA (2006) Involvement of oxidative stress in Alzheimer disease. J Neuropathol Exp Neurol 65, 631-641.

[279] Sun GY, He Y, Chuang DY, Lee JC, Gu Z, Simonyi A, Sun AY (2012) Integrating cytosolic phospholipase 
A2 with oxidative/nitrosative signaling pathways in neurons: A novel therapeutic strategy for AD. Mol Neurobiol 46, 85-95.

[280] Sano M, Ernesto C, Thomas RG, Klauber MR, Schafer K, Grundman M, Woodbury P, Growdon J, Cotman CW, Pfeiffer E, Schneider LS, Thal LJ (1997) A controlled trial of selegiline, alpha-tocopherol, or both as treatment for Alzheimer's disease. The Alzheimer's Disease Cooperative Study. N Engl J Med 336, 1216-1222.
[281] Simonyi A, Serfozo P, Lehmidi TM, Cui J, Gu Z, Lubahn DB, Sun AY, Sun GY (2012) The neuroprotective effects of apocynin. Front Biosci (Elite Ed) 4, 2183-2193.

[282] Grossi C, Francese S, Casini A, Rosi MC, Luccarini I, Fiorentini A, Gabbiani C, Messori L, Moneti G, Casamenti F (2009) Clioquinol decreases amyloid-beta burden and reduces working memory impairment in a transgenic mouse model of Alzheimer's disease. J Alzheimers Dis 17, 423-440. 